\title{
Non-digestible oligosaccharides used as prebiotic agents: mode of production and beneficial effects on animal and human health
}

\author{
Damien Grizard*, Chantal Barthomeuf \\ Laboratoire de pharmacognosie et de biotechnologies, UFR de pharmacie, \\ Place H.-Dunant, 63001 Clermont-Ferrand cedex, France
}

(Received 28 June 1999; accepted 20 September 1999)

\begin{abstract}
Prebiotic agents are food ingredients that are potentially beneficial to the health of consumers. The main commercial prebiotic agents consist of oligosaccharides and dietary fibres (mainly inulin). They are essentially obtained by one of three processes: 1) the direct extraction of natural polysaccharides from plants; 2) the controlled hydrolysis of such natural polysaccharides; 3) enzymatic synthesis, using hydrolases and/or glycosyl transferases. Both of these enzyme types catalyse transglycosylation reactions, allowing synthesis of small molecular weight synthetic oligosaccharides from mono- and disaccharides. Presently, in Europe, inulin-type fructans, characterised by the presence of fructosyl units bound to the $\beta-2,1$ position of sucrose, are considered as one of the carbohydrate prebiotic references. Prebiotics escape enzymatic digestion in the upper gastrointestinal tract and enter the caecum without change to their structure. None are excreted in the stools, indicating that they are fermented by colonic flora so as to give a mixture of short-chain fatty acids (acetate, propionate and butyrate), L-lactate, carbon dioxide and hydrogen. By stimulating bifidobacteria, they may have the following implications for health: 1) potential protective effects against colorectal cancer and infectious bowel diseases by inhibiting putrefactive bacteria (Clostridium perfringens) and pathogen bacteria (Escherichia coli, Salmonella, Listeria and Shigella ), respectively; 2) improvement of glucid and lipid metabolisms; 3 ) fibre-like properties by decreasing the renal nitrogen excretion; 4) improvement in the bioavailability of essential minerals; and 5) low cariogenic factor. These potential beneficial effects have been largely studied in animals but have not really been proven in humans. The development of a second generation of oligosaccharides and the putative implication of a complex bacterial trophic chain in the intestinal prebiotic fermentation process are also discussed. (C) Inra/Elsevier, Paris
\end{abstract}

prebiotic agents / oligosaccharides / production / physiological effects / colon fermentation / short-chain fatty acids

\footnotetext{
* Correspondence and reprints

E-mail: Chantal.Barthomeuf@u-clermont 1.fr
} 
Résumé - Oligosaccharides non digestibles utilisés comme agents prébiotiques : mode de production et effets bénéfiques sur la santé humaine et animale. Les principaux agents prébiotiques sont des oligosaccharides ou des fibres alimentaires (essentiellement l'inuline) actuellement utilisés comme ingrédients alimentaires. Ces molécules sont principalement obtenues selon trois procédés : 1) extraction directe de polysaccharides naturels à partir des végétaux ;2) hydrolyse contrôlée de ces polysaccharides naturels ; 3 ) synthèse enzymatique d'oligosaccharides de faible masse moléculaire, obtenus par l'action d'une enzyme de transfert sur un mono- ou disaccharide. Actuellement, en Europe, les agents prébiotiques de référence sont des mélanges de fructanes de type inuline caractérisés par la présence de liaisons $\beta-2,1$ entre leurs unités fructosyles. Les agents prébiotiques ne sont pas digérés dans les parties hautes du tractus digestif et arrivent intacts dans le côlon où ils sont fermentés par la flore bactérienne endogène. La spécificité de ces composés pour les bifidobactéries coliques seraient responsables de leurs effets bénéfiques sur la santé de l'hôte. Ces implications favorables seraient principalement liées à : 1) une protection accrue contre les cancers et les pathologies infectieuses du côlon ; 2) une amélioration des profils lipidique et glucidique ; 3 ) une diminution de l'excrétion azotée rénale ; 4) une augmentation de la biodisponibilité des minéraux essentiels ; 5) une faible cariogénicité. À l'heure actuelle, la plupart de ces effets ont été prouvés chez le rat, mais ils ne sont pas démontrés chez l'homme. Le développement possible d'une nouvelle génération d'oligosaccharides et l'implication éventuelle d'une chaîne trophique bactérienne complexe dans la fermentation intestinale des prébiotiques sont également discutés. (C) Inra/Elsevier, Paris

agents prébiotiques / oligosaccharides / production / effets physiologiques / fermentation colique / acides gras volatils

\section{INTRODUCTION}

It has been demonstrated that more than 400 bacteria species are present in the human colon flora (with 40 species present in large quantities) and that any disturbance in the ecological balance, related, for example, to a change in diet or an antibiotic treatment can allow gastro-intestinal disorders from intestinal discomfort to severe symptoms such as diarrhoea and colitis [113, 170]. Changes in the colon flora have also been implicated in the development of colon cancers [170].

The colonic microflora is of crucial importance to any consideration of the role of food ingredients in health and disease since many physiological effects of such compounds are influenced by the activities of the colonic bacteria. Identification of the main organisms responsible for breakdown of food ingredients is not easy. The complexities of the colonic environment due to ecological relevance of non-culturable gut bacterial diversity which may markedly influence food ingredient fermentation are very difficult to take into account [148]. Moreover, degradation of food ingredients may require two or more bacteria acting in 'consortium'.

Manipulating the colon flora by stimulating the growth of potentially beneficial commensal bacteria such as bifidobacteria or lactobacilli can thus have positive effects on human health. This can be obtained by either prebiotic or probiotic oral consumption. Prebiotics have been defined by Gibson and Roberfroid [57] as "non-digested food ingredients that beneficially affect the host by stimulating the growth and activity of one or a limited number of bacterial species already residing in the colon". Probiotics are defined by Fuller [48] as "live microbial feed supplements which beneficially affect the host animal by improving its intestinal microbial balance". A combination of both probiotics and prebiotics forms synbiotics [57].

Undigestible carbohydrate (certain food oligosaccharides and polysaccharides) are 
possible prebiotics. This paper focuses on their structures as well as their speculative positive health benefits on nitrogen, carbohydrate and lipid metabolisms. Other benefits such as the increase in absorption of various ions such as calcium, magnesium and iron are also reviewed. The actual stage of research, from in vitro to animal or human in vivo experiments, is defined for each positive effect.

\section{THE MAIN OLIGOSACCHARIDES POTENTIALLY USEFUL AS PREBIOTIC AGENTS}

The main commercial food oligosaccharides (DP, 2-10), used as prebiotic agents, are essentially obtained by enzymatic technology, mainly enzymic synthesis using hydrolases and glycosyl transferases or partial enzymatic hydrolysis of natural longchain carbohydrate polymers. However, some direct plant-extracted polysaccharides (mainly inulin) have also been commercialised. The principal structures of oligosaccharides potentially useful as prebiotic agents are listed in table $I$.

\subsection{Inulin-type fructans}

Fructan (inulin- and levan-types) is a general name used for any carbohydrate in which one or more fructosyl-fructose link constitutes the majority of osidic bonds. Among fructans, only inulin-type fructans are used as prebiotic properties [147]. Inulin is a linear fructan consisting of two to more than 702,1 -linked $\beta$-D-fructofuranoside units. Because such polymers are synthesised from sucrose, by repeated fructosyl transfer from a fructosyl donor, inulin (usually, but not always), exhibits a terminal glucose unit [145]. It is an abundant energy storage carbohydrate present in many plants (Liliaceae, Amaryllidaceae and Compositae). Only a limited number of plant species are, however, suitable for industrial pre- biotic extraction [145]. The two species currently used by the food industry to produce inulin belong to the Compositae: Jerusalem artichoke (Helianthus tuberosus) and chicory (Cichorium intybus) [33]. The average inulin content in chicory root is about $15-20 \%$ fresh weight. In chicory inulin, both $\mathrm{G}_{p y} \mathrm{~F}_{\mathrm{n}}(\alpha-\mathrm{D}$-glucopyranosyl-[ $\beta$-D-fructofuranosyl $]_{n-1}-D$-fructofuranoside) and $F_{p y} F_{n}(\beta-D$-fructopyranosyl- $\alpha-D$-fructofuranosyl $]_{n-1}$-D-fructofuranoside) compounds are considered to be included under the same nomenclature [145]. The various fructose monomers in the $\mathrm{G}_{\mathrm{py}} \mathrm{F}_{\mathrm{n}}$ forms of inulin are all present in the furanose form. Only in the $\mathrm{F}_{\mathrm{py}} \mathrm{F}_{\mathrm{n}}$ forms is the reducing fructose in the pyranose form [34]. Native chicory inulin has an average DP of 10-20, whereas for native Jerusalem artichokes, the average DP is 6 [35]. Native inulin is used by the food industry to produce: 1) short-chain fructans, namely oligofructose (DP, 2-10; average $\mathrm{DP}, 5)$, as a result of partial enzymic hydrolysis (endoinulinase EC 3.2.1.7); and 2) long-chain fructans by applying physical separation technique [35]. Inulin is mostly marketed by Orafti (Tienen, Belgium) and Cosucra (Momalle, Belgium) under the trade names 'Raftiline' and 'Fibruline', respectively [30]. The partial enzymatic hydro-lysate of inuline is marketed by Orafti as 'Raftilose' in a variety of purities, either as a powder or in syrup form. The chicory inulin and its hydrolysate are: 1) classified as natural food ingredients [178]; 2) officially recognised as food ingredients in most European countries; 3 ) have a self-affirmed GRAS (generally regarded as safe) status in USA [144].

In addition to chicory inulin and its hydrolysate, the commercially prebiotic inulin-type fructans are a mixture of synthetic $\mathrm{G}_{\mathrm{py}} \mathrm{F}_{\mathrm{n}}$ oligomers (average DP, 3.6). For instance, synthetic inulin-type fructans commercialised by Beghin-Meiji Industries (Actilight) are mixtures of oligosaccharides including 1-kestose (DP 3), 1-nystose (DP 4) and 1 -fructofuranosyl-nystose (DP 5) with unreacted sucrose, glucose and fructose con- 


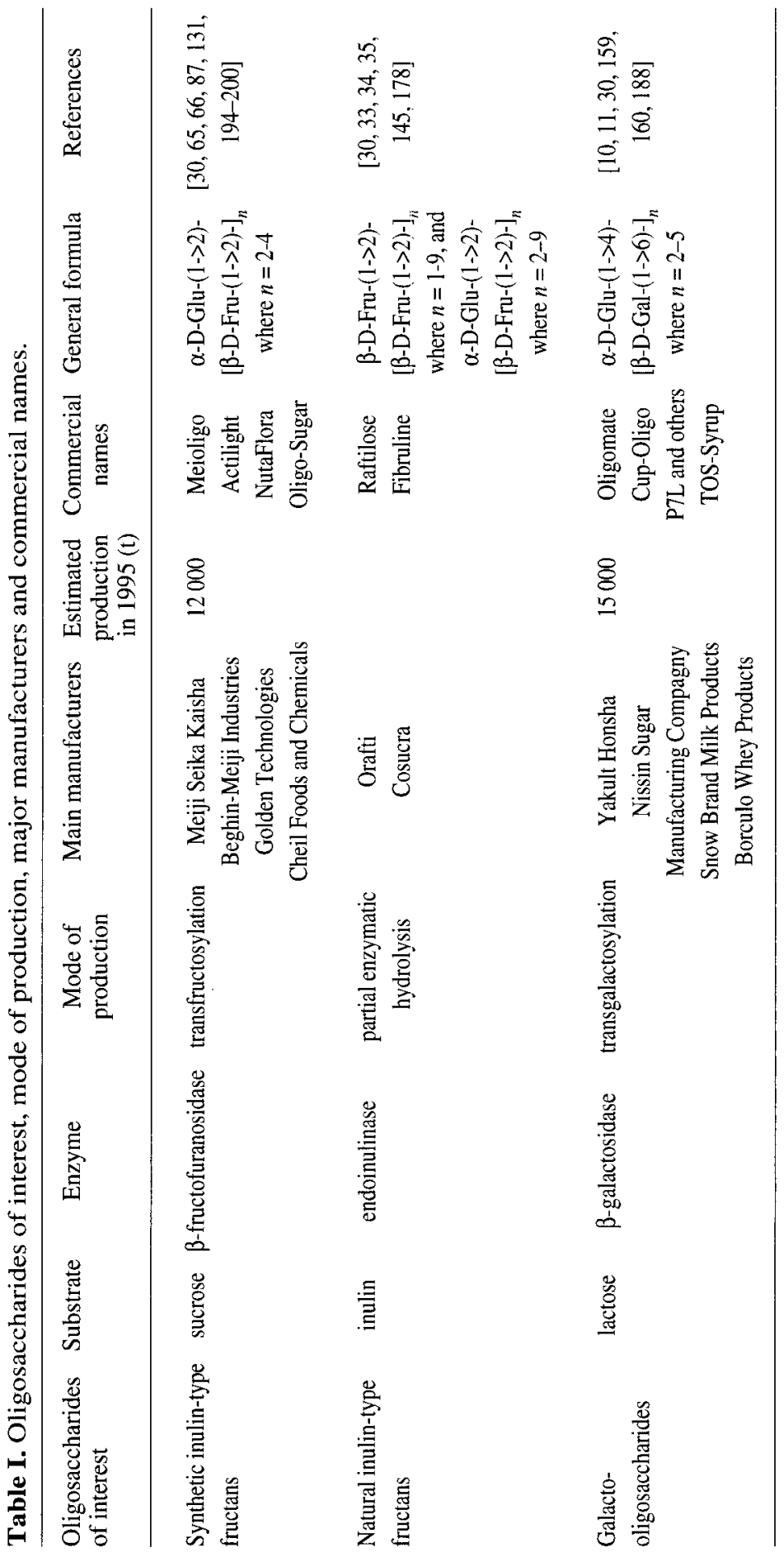


Oligosaccharides as prebiotic agents

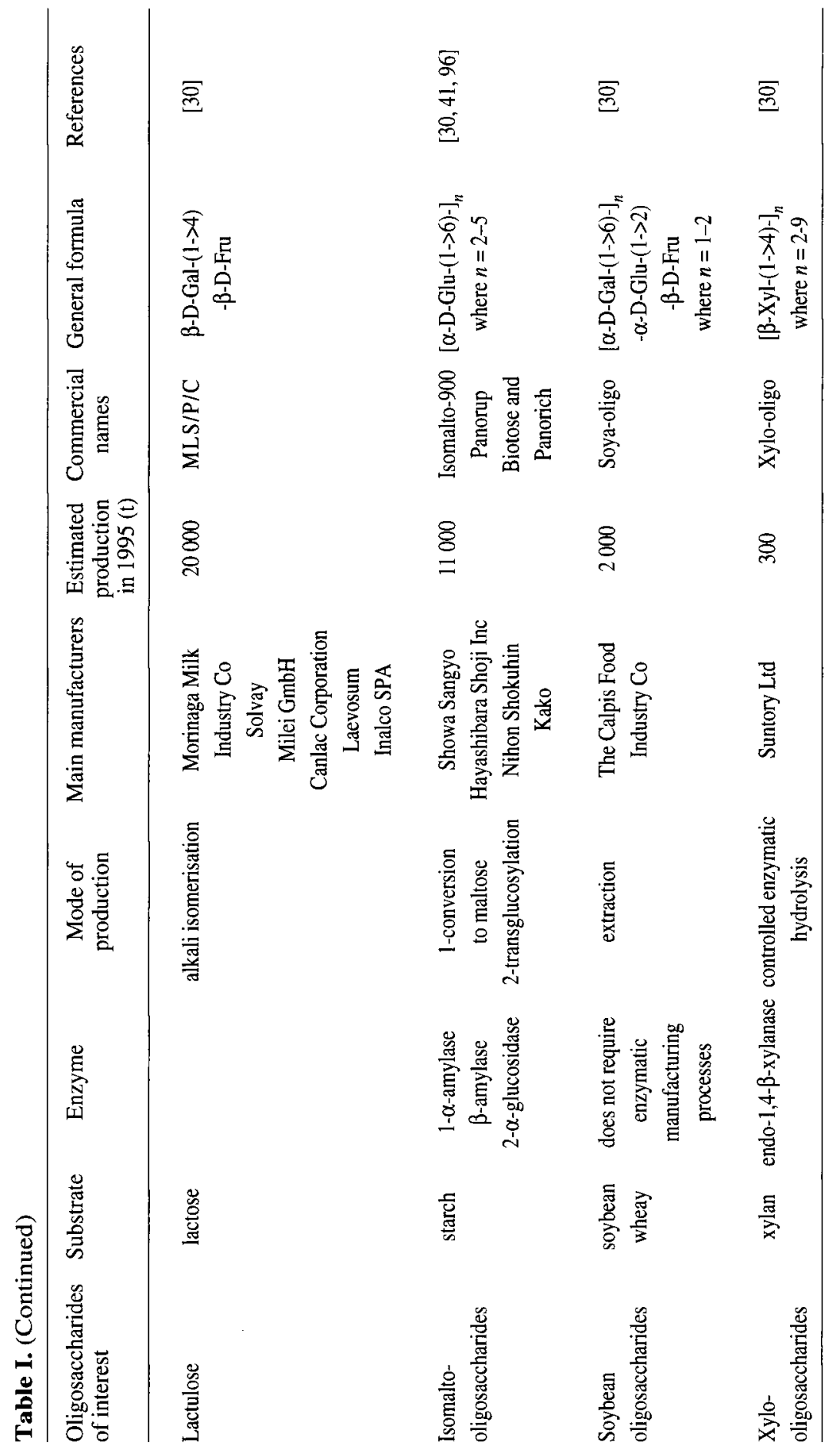


taining between 55 and $95 \%$ oligofuctans. They result from transfructosylation of sucrose with a fungal fructosyl transferase from Aureobasidium pullulans $[80,199]$ or Aspergillus niger [68]. The main drawback of this mode of preparation is the low conversion yield $(55-60 \%)$ related to the liberation of glucose that acts as a competitive inhibitor. To improve the conversion yield, numerous solutions have been investigated such as the use of a mixed system of glucose oxidase and fructosyltransferase [198].

\subsection{Galacto oligosaccharides (GOS)}

GOS are mainly produced commercially from lactose by transgalactosylation of $\beta$-D-galactosidases (lactase) derived from Bacillus circulans $[10,11,30,116,188]$. The main products are the trisaccharide, $\mathrm{Gal} \beta(1-4) \mathrm{Gal} \beta(1-4) \mathrm{Glc}$ and the tetrasaccharide, Gal $\beta(1-4)$ Gal $\beta(1-4) G a l \beta(1-4) G l c$. Monosaccharides formed as by-products as well as unreacted lactose are removed from the GOS mixture by a cation-exchange resin.

\subsection{Isomalto oligosaccharides (IMO)}

Commercially available IMO are a mixture of $\alpha(1->6)$ link glucosides such as isomaltose (DP 2), isomaltotriose (DP 3), panose (DP 3), isomaltotetraose (DP 4), isomaltopentaose (DP 5) and isomaltohexaose (DP 6).

IMO are enzymatically manufactured from starch using a two-step reaction: 1) conversion of starch to maltose by a mixture of $\alpha$ and $\beta$ amylase; and 2) the transglucosidase activity of $\alpha$-glucosidase [30].

\subsection{Soybean oligosaccharides}

Preparation of soybean oligosaccharides does not require an enzymatic manufacturing process. They are directly extracted from soybean whey [30].

\subsection{Xylo oligosaccharides}

Xylo oligosaccharides are produced from the polysaccharide xylan which is extracted from corncobs by endo-1,4- $\beta$-xylanase hydrolysis [30].

\subsection{Lactulose}

Lactulose (4-O- $\beta$-D-galactopyranosylD-fructo-furanose) is a keto analogue of lactose. In contrast to other prebiotic compounds, lactulose is not obtained by an enzymatic process but by alkali isomerisation of lactose which converts the glucose moeity to a fructose residue.

Lactulose is used as a prebiotic food ingredient [153] but due to its low sweetness it does not have many food applications. Lactulose, however, has a number of applications in pharmaceutical preparations for treatment of constipation and hepatic encephalopathy $[13,135]$.

\section{SELECTIVE FERMENTATION IN THE GASTRO-INTESTINAL TRACT}

\subsection{Generalised scheme}

Non-digestible carbohydrates reach the large intestine where they are used by the resident saccharolytic microflora, so as to give bacterial biomass and various intermediate and end products including gases (hydrogen, carbon dioxide and methane), short-chain fatty acids (SCFA: mainly acetate, propionate and butyrate), organic acids (lactate, succinate and pyruvate) and ethanol $[32,136]$.

After absorption, SCFA are metabolised by various tissues: butyrate by the colonic epithelium; propionate, L-lactate and acetate (partly) by the liver; and acetate (partly) by muscle (partly) [40, 140, 158]. It has been shown that a portion of $\mathrm{H}_{2}$ is excreted in the breath [1]. 


\subsection{Inulin-type fructans}

Inulin-type fructans escape from enzymatic digestion in the upper part of the digestive tract and enters the caecum without any significant change in structure because the $\beta-2,1$ osidic bond cannot be hydrolysed by mammalian digestive enzymes $[150,166]$. In addition, Oku et al. [129] demonstrated that the $\beta-2,1$ linkage is not hydrolysed by rat pancreatic homogenates and small intestinal mucosa homogenates. These results have also been confirmed in humans by Bach Knudsen and Hessov [6] and Ellegärd et al. [44], using the ileostomy model which has often been used to quantify the small-intestinal excretion of carbohydrates [31]. As a result, the major part of ingested inulin-type fructans (in healthy humans, a mean of $89 \%$ ) is delivered to the colon in an unhydrolysed form [112].

Inulin-type fructans are fermented by colonic bacteria [14] according to the following stoichiometry [146]:

$$
\begin{gathered}
1 \mathrm{C}_{6} \mathrm{H}_{12} \mathrm{O}_{6} \geq 1.5 \mathrm{CH}_{3} \mathrm{COOH} \\
+0.33 \mathrm{CH}_{3} \mathrm{CH}_{2} \mathrm{COOH} \\
+0.15 \mathrm{CH}_{3}\left(\mathrm{CH}_{2}\right)_{2} \mathrm{COOH} \\
+0.33 \mathrm{CH}_{3} \mathrm{CHOHCOOH}^{+} \\
+0.33 \mathrm{CO}_{2}+0.33 \mathrm{H}_{2} \mathrm{O}
\end{gathered}
$$

In terms of carbon atoms, the reaction yields $40 \%$ SCFA, $15 \%$ L-lactate, $5 \%$ carbon dioxide and $40 \%$ bacterial biomass. Finally, inulin-type fructans are not excreted in stool or urine samples $[1,112]$.

In vitro, in rats as well as in humans, inulin-type fructans were reported to promote the growth of some species of the indigenous microflora, especially bifidobacteria, one of the potential health-promoting populations in the colonic microbiota $[51,68,142,143,145,147]$. Such a modification has clearly been demonstrated in humans by Gibson et al. [58] who reported that, after ingesting oligofructose and inulin $\left(15 \mathrm{~g} \cdot \mathrm{d}^{-1}\right)$ for 2 weeks, bifidobacteria become the predominant genus in faeces. This stimulating effect is no doubt related to the $\beta$-fructosidase production by bifidobacteria as demonstrated by Wang [182] with pure culture or Bouhnik et al. [15] in humans.

Inulin and oligofructose are nondigestible carbohydrate food ingredients that meet all the criteria that are needed to be recognised as prebiotics [57, 59], i.e. inulintype fructans may have beneficial implications for health by selectively stimulating the growth of colonic bifidobacteria.

\subsection{IMO}

The ability of IMO to be fermented in the colon has been assessed from the amount of $\mathrm{H}_{2}$ in the breath since this gas cannot be produced by human cells. Its appearance in breath is related to colonic fermentation. For example, breath $\mathrm{H}_{2}$ increases after ingestion of non-absorbable maltitol, lactulose or GOS carbohydrates [169]. In contrast, $\mathrm{H}_{2}$ in breath disappears within $2 \mathrm{~h}$ of glucose or maltose ingestion. Normal resting healthy volunteers excreted a total $52 \pm$ $6.5 \mathrm{~mL} \mathrm{H}$ over a 6 -h period after maltitol intake. This excretion was only $13.0 \pm$ $0.8 \mathrm{~mL}$ with IMO, suggesting that IMO fermentation was only $25 \%$ of that for maltitol [92].

Enrichment in breath of ${ }^{13} \mathrm{CO}_{2}$ after ${ }^{13} \mathrm{C}$ labelled carbohydrate intake also provides an index of carbohydrate metabolism. Control maltose yielded 34.5 and $88.4 \%{ }^{13} \mathrm{C}$ recoveries in healthy volunteers in resting and exercise conditions, respectively. The corresponding values with IMO were only 28.7 and $60.9 \%$, indicating that IMO are metabolised at a lower rate than maltose [92]. This is consistent with colonic fermentation of IMO.

IMO can be resolved on high performance liquid chromatography (HPLC) into a number of fractions, e.g. small molecular weight compounds (mainly disaccharides, IM2), high molecular weight compounds (mainly tri- and tetrasaccharides, IM3). IMO, IM2, IM3 and an hydrogenated derivate of IMO (IMH) have been characterised 


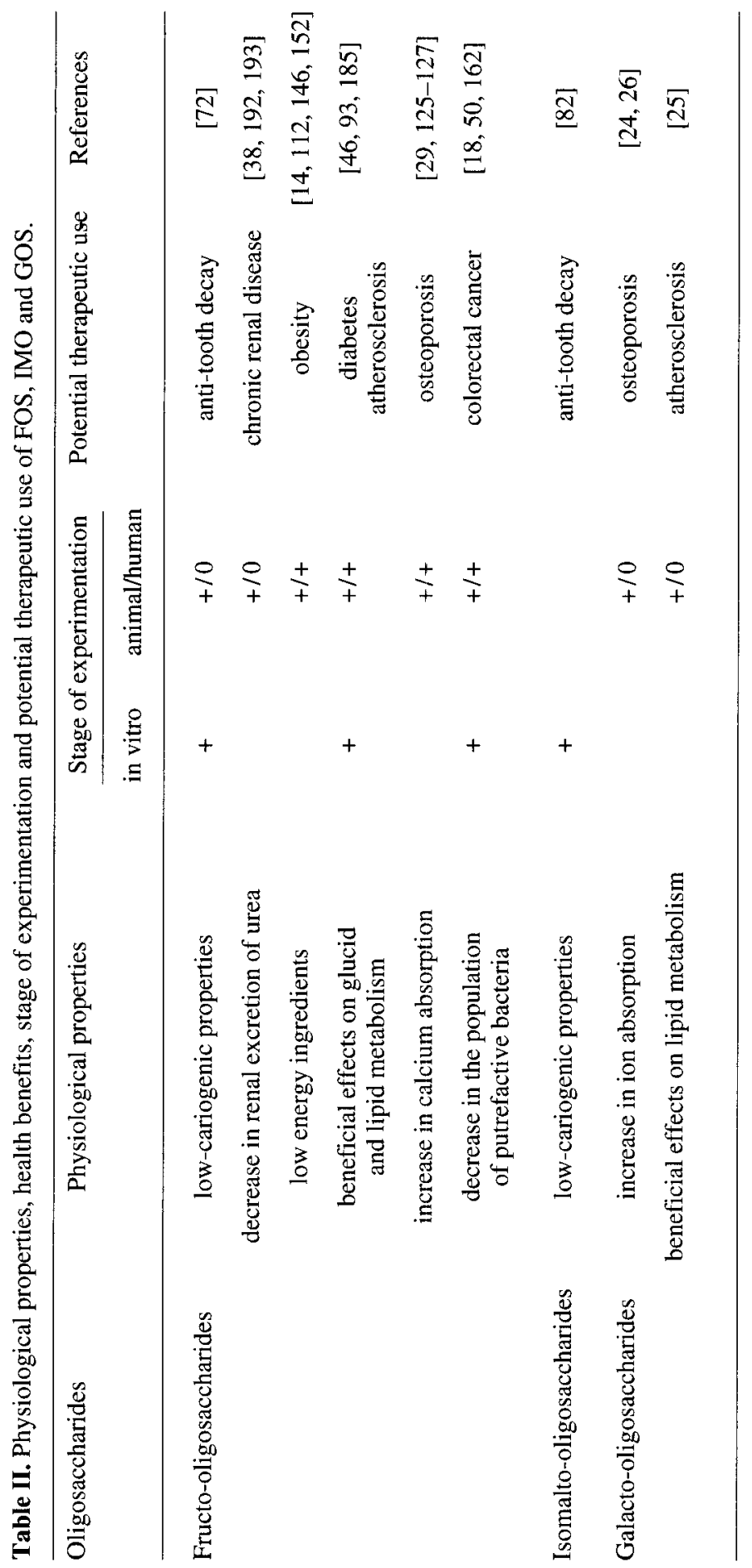


using their luminal clearance from rat jejunum loops as an indication of their digestibility [83]. The jejunum was chosen because it exhibits the highest digestive enzyme activities. The clearance rate of IMO is intermediate between typical control digestible and non-digestible carbohydrate. The clearance of IM2 is close to the clearance of digestible carbohydrate, whereas that of IM3 tends to have the same behaviour as indigestible carbohydrate. It may be inferred that highly polymerised IMO have to be sequentially degraded before being absorbed and therefore have lower digestibility. Hydrogenation of IMO leads to a typical non-digestible carbohydrate behaviour.

IMO were studied for their potency to stimulate the growth of bifidobacteria in the faeces of healthy humans. The minimum intake of IMO needed to induce a significant and selective effect was around $9 \mathrm{~g} \cdot \mathrm{d}^{-1}$ for a 14-d period [91]. This was achieved by $10 \mathrm{~g} \cdot \mathrm{d}^{-1}$ for a $12-\mathrm{d}$ period and $5 \mathrm{~g} \cdot \mathrm{d}^{-1}$ also for a 12-d period with IM2 and IM3, respectively [81]. The differences between IM2 and IM3 in their ability to stimulate bifidobacteria in vivo are only related to their digestibility because they have the same potency in vitro [81].

In contrast to oligofructose, IMO cannot be considered as a pure prebiotic agent because they are partly digested by isomaltase in the jejunum and only the remainder stimulates bifidobacteria in the large intestine. Consequently, the minimum dosage of IMO for increasing intestinal bifidobacteria in humans is higher than that needed for oligofructose to obtain such an effect $\left(1-2 \mathrm{~g} \cdot \mathrm{d}^{-1}\right.$ for $10 \mathrm{~d}$ ) [91]. IMO is therefore only a colonic food ingredient.

\subsection{GOS, soybean oligosaccharides, xylo oligosaccharides and lactulose}

As for inulin-type fructans, the GOS, soybean oligosaccharides, xylo oligosaccharides and lactulose also increase bifidobac- teria. It has been established that a prolonged administration of GOS at a dose which does not induce digestive symptoms $\left(10 \mathrm{~g} \cdot \mathrm{d}^{-1}\right.$ for $21 \mathrm{~d}$ ), increases the number of bifidobacteria and changes the fermentative activity of colonic flora in humans by increasing acetate proportion and lactate formation [16]. Kikuchihayakawa et al. [85] demonstrated that the time period of GOS feeding, in the rat, influenced the production rate of lactic acid, acetic acid, propionic acid and butyric acid. Lactulose is also well known for its significant promoting effect on lactic acid bacteria (Lactobacillus acidophilus) and bifidobacteria in humans [153, 172]. Regarding dietary xylo oligosaccharides, a stimulated effect on the growth of bifidobacteria in rats, accompanied by a modest enhancement of faecal epithelial cell proliferation has been observed [71]. Experimental results tend to indicate that GOS, soybean oligosaccharides and lactulose may be considered as pure prebiotic agents [75, 77, 151, 169].

\section{HUMAN AND ANIMAL HEALTH BENEFITS}

Physiological properties, health benefits, stage of experimentation and potential applications of inulin-type fructans, IMO and GOS in risk reduction of diseases are listed in table II.

\subsection{Effect on intestinal pathologies}

Changes in the composition of human diets can alter the balance of colonic bacteria in a favourable manner $[15,27,165$, 190]. Interestingly, one of the main potential benefits of increasing human faecal bifidobacteria is that bifidobacteria could maintain potential pathogenic bacteria such as Escherichia coli and clostridia at low levels $[183,186]$. Such results are, however, restrictive because they were observed in batch culture experiments with human faeces as the source of inoculum [55]. The lim- 
itations are caused by the fact that the multiple stage continuous culture system as described by Macfarlane et al. [105] often used, cannot reproduce the precise complexity of the proximal and distal colons. Moreover, both continuous and semi-continuous systems use freshly collected human faeces from a single donor as the source of inoculum and do not take into account variations within a wider population. The selective fermentation of oligofructose by bifidobacteria along with the decrease in potential pathogenic bacteria has also been recorded in humans. For example, a daily intake of $15 \mathrm{~g}$ oligofructose during a 2-week feeding period results in an increase in the percentage of bifidobacteria in faeces from 6 to 22 , whereas the percentage of global bacteroides, clostridia and fusobacteria decreases (25-4; $1-0.2$ and $4-0.4$, respectively) [58]. In a similar fashion, a $15 \mathrm{~g} \cdot \mathrm{d}^{-1}$ dietary supplement of inulin in humans, leads to bifidobacteria becoming the predominant genus in faeces $\left(9.2-10.1 \mathrm{Log} 10 \cdot \mathrm{stool}^{-1}\right)$ and this phenomenon is associated with a decrease in gram-positive cocci.

The potential indirect protective effect of inulin-type fructans via bifidobacteria, related to their inhibitory effect on bacteria which are potentially implicated in bowel diseases, could be explained by the decrease in $\mathrm{pH}[54,183]$. Acidification of colonic contents are probably caused by the appearance of acetate and lactate [183]. Alternatively, using coculture experiments, it has been reported that bifidobacteria may secrete a bacteriocin-type substance against Escherichia coli, salmonella, listeria, camylobacter and shigella as well as Vibrio cholerae [56, 57]. Also, Oyarzabal and Conner [130] have demonstrated by an in vitro study that inulin-type fructans are able to inhibit salmonella, which are often implicated in infectious bowel diseases, by two distinct mechanisms. 1) In media including only oligofructose as the carbohydrate source, none of the following salmonella serotypes S. california, S. enteridis, $S$. heidelberg, S. mission, S. senftenberg and
S. typhimurium grow. This suggests that salmonella are not able to use inulin-type fructans as growth substrates. 2) Oligofructose stimulates the development of Enterococcus faecium, Lactococcus lactis and Pediococcus sp., which are known to inhibit the previously mentioned salmonella serotypes. These results are in accordance with the fact that inulin-type fructans reduce susceptibility to salmonella colonisation in chickens. Feeding chickens with a $0.7 \%$ oligofructose leads to a four-fold reduction in the level of Salmonella in the caecum [8]. Interestingly, a diet supplemented with oligofructose in broilers has no detrimental incidence on live performance and carcass characteristics [181]. Other mechanisms, such as competition for substrates and mucosal attachment sites and the stimulation of the enteric immune system [177, 187] could explain this inhibitory effect on potentially harmful microflora.

Putrefactive bacteria may be involved in the development of colorectal cancer through the appearance of toxins and carcinogens from endogenous and exogenous substrates [21]. For instance, Clostridium perfringens, through the action of the $7 \alpha$-dehy-droxylase, is responsible for the conversion of primary to secondary bile acids in the colon. Based on the structural similarity of certain secondary bile acid derivatives to polycyclic aromatic hydrocarbon carcinogens, secondary bile acids are considered as possible tumour promoters [69]. Because $\beta$-glucuronidase and nitroreductase can release aglycones from glycosides, producing reactive nitroso and $\mathrm{N}$-hydroxy compounds, respectively, within the colon, they are also potential procarcinogenic enzyme producers $[63,161]$. $\beta$-Glucuronidase and nitroreductase are normally produced by anaerobic bacteria such as bacteroides and Clostridium, and facultative anaerobes such as coliforms [62]. Other reductive enzymes such as urease, by converting urea into ammonia, are possible aetiological factors in colorectal carcinoma [161]. One of the main potential benefits of 
increasing colonic levels of bifidobacteria by chronic inulin-type fructan ingestion could be the reduction in risk of colon cancer [111]. Decreased pH may inhibit the growth of putrefactive bacteria and the conversion of primary to secondary bile acids [164]. Lower $\mathrm{pH}$ may also stimulate the production of a protective agent, e.g. mucus [19]. Finally, the protective effect of bifidobacteria is expressed through their potency at decreasing some reductive enzyme activities. Accordingly, Buddington et al. [18] indicated that consumption of oligofructose $\left(4 \mathrm{~g} \cdot \mathrm{d}^{-1}\right)$ in human subjects induces an increase in bifidobacteria along with a decrease in $\beta$-glucuronidase and glycocholic acid hydroxylase activities by 75 and $90 \%$, respectively. Both reductive activities increase after interruption of oligofructose supplementation. Kulkarni et al. [95] showed that increasing the proportion of bifidobacteria is related to lower activities of reductive enzymes. These results must, however, be considered with caution since Bouhnik et al. [15] demonstrated that there is no change in reductive activities (e.g. nitroreductase, azoreductase and $\beta$-glucuronidase), in the concentrations of bile acids and neutral sterols after a 12-day oligofructoseinduced bifidobacteria growth period in humans. The origin of the discrepancy between the above studies is not known. Bouhnik et al. [15] suspect that the possibility of subsequent changes in the parameters studied could start after the increase in faecal Bifidobacterium levels and could appear after 12 days. The protective effect of bifidobacteria against colorectal cancer has also been demonstrated in studies in rats, where inulin-type fructan ingestion results in a state of resistance to the effect of the exogenous carcinogenic agent, 1,2 dimethylhydrazine (DMH) [50] and 2-amino3-methylimidazol (4,5-F) quinoline [138]. Inulin-type fructans are also able to inhibit azoxymethane (AOM)-induced preneoplastic lesion formation such as aberrant crypt foci (ACF), an early preneoplastic marker of malignant potential in the pro- cess of colon carcinogenesis in rats [133, $137,139,149]$.

Other undigestible oligosaccharides are equally known to have beneficial effects on various factors potentially involved in the pathogenesis of colon cancer. Challa et al. [22] demonstrated that Bifidobacterium in association with lactulose suppresses azoxymethane-induced colonic aberrant crypt foci in rats. Moreover, dietary supplementation of humans with lactulose leads to an increase in the number of bifidobacteria, whereas the numbers of Clostridium perfringens and Bacteroidaceae decrease. These variations in colonic flora have the following consequences: 1) a reduced activity of faecal pro-carcinogenic enzymes (e.g. azoreductase, $7 \alpha$-dehydroxylase, $\beta$-glucuronidase, nitroreductase and urease activity; 2) decreased faecal aromatic compound concentrations (e.g. phenol, cresol, indole and skatol) $[9,172]$. GOS are also reported to lower faecal nitroreductase activity and the concentrations of indole and isovaleric acid in humans [77]. The potential antitumour activity of certain undigestible carbohydrates (i.e. inulin-type fructans, GOS and lactulose) seems to be related to their prebiotic properties because it has been demonstrated that administration of probiotic Bifidobacterium longum significantly inhibits azoxymethane (AOM)-induced cell proliferation $[95,137,162]$.

In conclusion, the literature shows that the addition of prebiotic agents in the diet could alter, both in rats and humans, the concentrations of bifidobacteria and the intracolonic fermentation metabolism. This in turn, by normalising the intestinal flora, may be associated with the reduction of various factors potentially involved in colonic disorders. For instance, oligofructose, GOS and lactulose supplementations significantly depressed excretion of isobutyrate and isovalerate $[2,76]$. These SCFA originate from protein fermentation [103]. Protein fermentation produces not only SCFA but also indoles and ammonia. These products might 
have a toxic effect on mucosa [134]. Thus, we speculate that prebiotic agents are promising as dietary food ingredients for patients submitted to surgery related to intestinal disturbances such as ulcerative colitis or familial adenomatous polyposis [2]. Adding prebiotic agents to the diet of patients with an ileal-anal anastomosis (a surgical alternative to permanent ileostomy in patients with ulcerative colitis or familial adenomatous polyposis), through their potential protein fermentation lowering effect, may decrease cytotoxicity of pouch contents [2].

\subsection{Low energetic value}

It is clear that colonic fermentation by indigenous bacteria of dietary prebiotic agents decreases their energetic value [38]. The loss of energy for the host when a sugar is fermented is caused by: 1) the growth of bacteria which in turn releases part of the energy as heat dissipation; 2) the formation of SCFA and gas [14]. The SCFA (acetate, propionate and butyrate) are absorbed by the large intestine and mainly used by the liver and peripheral tissues (muscle and adipose tissue) as fuel. Based on biochemical balance charts for carbon atoms, metabolic pathways and energy yield to the host, the caloric value of a fructosyl unit of inulintype fructans was found to be approximately 25-35\% that of a digested molecule of hexose $[36,146]$. Thus, the energy value of oligofructose would range between 8.4 and $9.2 \mathrm{~kJ} \cdot \mathrm{g}^{-1}$ [112]. This caloric value $(8.4-9.2$ $\left.\mathrm{kJ} \cdot \mathrm{g}^{-1}\right)$ is higher than the $6.3 \mathrm{~kJ} \cdot \mathrm{g}^{-1}$ reported by Hosaya et al. [70]. This discrepancy is probably related to the methodology used. Hosoya et al. [70] used a very low mean energy content for SCFA $\left(10.0 \mathrm{~kJ} \cdot \mathrm{g}^{-1}\right)$ to calculate the energy value of oligofructose compared to Molis et al. [112] (acetic 10.9-12.6, propionic 15.5-17.6 and butyric acids $18.8-21.3 \mathrm{~kJ} \cdot \mathrm{g}^{-1}$, respectively). The caloric value of oligofructose, therefore, appears lower than that of polyols such as sorbitol $\left(8.4-10.9 \mathrm{~kJ} \cdot \mathrm{g}^{-1}\right)$ or maltitol
(11.7-13.4 kJ.g $\mathrm{g}^{-1}$ [14]. Contributions to energy accumulation in rats tend to be different between oligofructose and GOS [152]. The differences in energetic contribution between these two undigestible oligosaccharides are no doubt related to the relative amounts of each organic acid produced in the large intestine [152]. Consequently, the viscous longer-chain oligosaccharide products such as inulin can be used as a fat replacer for the emerging sector of lower energy food products [146].

\subsection{Effect on lipid and glucose metabolisms}

During the last few years, several literature reviews reporting the nutritional impact of chronic fermentable carbohydrate feeding on lipid metabolism in animals (mostly rats, hamsters and guinea-pigs) have been published. These studies were mainly performed with a great variety of fibre sources (i.e. wheat bran, cellulose, lignin, oat bran, pectins and guar gum) [97]. These complex carbohydrates have been found to display a significant lowering effect on plasma cholesterol and triglycerides $[3-5,42,52$, $74,167,174]$. The high viscosity of these dietary compounds could play an important role in this lipid-depressing effect $[97,156]$. Other mechanisms could also be involved. Due to their physico-chemical properties, it is now apparent that one major mechanism responsible for the hypocholesterolemic action of fibres may be related to their binding capacities of dietary or biliary cholesterol in the intestinal lumen $[45,49$, $97,107,109,174]$. The subsequent increase in faecal output of biliary acids leads in turn to a net stimulation of hepatic cholesterogenesis, through an increase in 3-hydroxy3-methylglutaryl $\mathrm{CoA}$ reductase (HMG$\mathrm{CoA}$ ) activity (the rate-limiting enzyme of cholesterogenesis) [109]. The cholesterollowering effect of high fibre could also stimulate in turn the liver uptake of lipoprotein cholesterol by up-regulating low density lipoprotein (LDL) receptor activity [176]. 
Regarding prebiotics, it has been observed that rats fed a diet containing $10-15 \%$ oligofructose show a significant reduction in body fat deposition, triglyceridaemia $(-35 \%)$ and phospholipidaemia $(-25 \%)$ by decreasing the number of circulating very low density lipoprotein (VLDL) particles [36, 37, 46, 93]. Moreover, Chonan et al. [25] demonstrated that GOS normalise the serum lipid profile of ovariectomised rats and blunt their hypercholesterolaemia. Regarding humans, hyperglycaemia and hyperlipidaemia are often recorded in non-insulin-dependant diabetes mellitus patients. A daily intake of oligofructose $\left(8.0 \mathrm{~g} \cdot \mathrm{d}^{-1}\right)$ for 14 days significantly reduces the fasting blood glucose and serum cholesterol levels in these diabetic subjects [185]. The levels of serum high density lipoprotein (HDL)-cholesterol, triglycerides or free fatty acids are not significantly affected by oligofructose [185]. A reduction of triglyceride concentrations was, however, observed in chronic renal-failure patients fed oligofructose $\left(9 \mathrm{~g} \cdot \mathrm{d}^{-1}\right)$ for three months [168].

Inulin-type fructans or GOS are less viscous than very high molecular weight polysaccharides, suggesting that in contrast to fibres, viscosity is not the most predominant factor involved in their lipid-lowering effects. Kok et al. [93] have demonstrated that oligofructose feeding could decrease the hepatocyte capacity for fatty acid synthesis and esterification through modulation of fatty acid synthetase (FAS) and glycerol-3-phosphate acyltransferase (GPAT) activities. Moreover, the decrease of lipogenesis in the liver could explain in part the observed reduction in VLDL-triglyceride secretion in FOS-fed rats [93]. To determine the precise depressing mechanism of inulin-type fructans on the lipogenic enzyme activity and the VLDL-triglyceride secretion capacity of liver cells, further works should however, be performed. Insulin and glucose have been shown to be important effectors regulating fatty acid and triglyceride synthesis $[60,84]$. FAS and GPAT activities and transcription are primarily activated by glucose and insulin [60,79]. Results of studies using rat liver perfusions or isolated hepatocytes indicate that insulin could also stimulate VLDL secretions [12]. Therefore, several authors postulate that oligofructose by decreasing insulinaemia and glycaemia [93, 185] may induce a reduction in fatty acid and triglyceride synthesis which in turn could decrease VLDL secretions by the liver $[53,163]$. Inulin-type fructans and GOS are largely fermented in the caeco-colon, leading to more than twofold increase in the propionate and acetate concentrations [37]. Propionate may be one possible mediator of hypolipidaemic effects of prebiotics because: 1) propionate has been reported to inhibit hepatic fatty acid synthesis $[100,118] ; 2)$ possibly, that propionate may have hypocholesterolaemic effect through its action on $\mathrm{HMG}-\mathrm{CoA}$ reductase activity $[73,184]$. All the postulates were made, however, based on studies using isolated hepatocytes or animals and could not exactly reflect the human state. Discrepancy may appear between humans and animals. For example, a marked lowering effect of plasma cholesterol in rats induced by fermentable polysaccharides seems to affect all the lipoprotein fractions (LDL, HDL1 and HDL2). Such an effect could not be directly extrapolated to humans, whose plasma cholesterol is mainly carried by the LDL fraction [99, 109]. More research should be performed in these areas to elucidate the metabolic regulation involved and to confirm these results in humans. We speculate, however, that prebiotic agents may be of great interest from a preventive and in a lesser part, 'therapeutic' point of view for pathologies related to hyperlipidemia such as atherosclerosis.

\subsection{Effect on nitrogen metabolism}

Dietary protein that escapes digestion as well as endogenous proteins from pancreatic and intestinal secretions and sloughed 
epithelial cells represents the main source of nitrogen for bacterial growth [106]. Blood urea can also be used especially by highly ureolytic bacteria in the caecum [98]. Indeed, a concentration gradient stimulates a net transfer of urea from the blood to the caecal lumen. Urea is degraded into ammonia by bacterial ureases and is then incorporated into microbial protein. These microbial proteins are finally eliminated in the faeces $[115,180]$. More urea is used in this pathway when the colonic flora is increased by oligofructose in the diet. Consequently, renal nitrogen excretion is depleted. For example, the addition of oligosaccharides such as oligofructose and xylo oligosaccharides to the diet $(7.5 \mathrm{~g}$ per $100 \mathrm{~g}$ of diet) in rats reduces blood urea and nitrogen in urine by 20-30\% [192]. Faecal nitrogen excretion and urinary nitrogen can be equal (approximately $50 \%$ of total nitrogen excretion by each route) when dietary indigestible carbohydrates such as oligofructose and soluble and insoluble fibres (insoluble oat fibres, soy polysaccharides, gum arabic and carboxymethylcellulose) are increased within nutrition acceptable ranges in parallel with a decrease in dietary protein levels [193].

This decrease in renal nitrogen excretion after feeding oligosaccharides may therefore be of interest in the nutrition of chronic renal disorders.

\subsection{Metabolic absorption of Ca, $\mathrm{Mg}$ and $\mathrm{Fe}$}

Dietary oligofructose $\left(50 \mathrm{~g} \cdot \mathrm{kg}^{-1}\right.$ diet $)$ significantly facilitates colorectal absorption of $\mathrm{Ca}$ (by $28 \%$ ) and $\mathrm{Mg}$ (by $41 \%$ ) in rats $[38,122]$. Results of other previous studies have indicated that apparent absorption is increased by $15-30 \%$ for $\mathrm{Ca}$ and $20-40 \%$ for $\mathrm{Mg}$, when oligofructoses are consumed at the same level (5\%) [119-121]. The stimulative effects of oligofructose on the absorption of $\mathrm{Ca}$ and $\mathrm{Mg}$ are about five times higher than those of lactose [119] and occur in the hindgut $[121,127]$.
Many investigators have suggested that this increase in mineral absorption is related to the colonic bacterial fermentation of these undigestible carbohydrates [39, 157, 189]. Carbohydrates that escape digestion in the small intestine are substrates for the formation of SCFA and lactate by microflora in the large intestine. This fermentation process results in a lowering of the luminal $\mathrm{pH}$ which in turn may increase mineral solubility $[141,157]$. It is conceivable that SCFA may directly influence $\mathrm{Ca}$ absorption by modifying electrolyte exchanges $(\mathrm{Ca}-\mathrm{H})$. Trinidad et al. [175] suggested that Ca could pass through the cell membrane more readily in the form of a less-charged complex (Ca acetate) $)^{+}$by a passive pathway. Lutz and Scharrer [102] also reported a stimulatory effect of SCFA on Ca absorption in the rat large intestine. The rat caecum has the highest density of $\mathrm{Ca}$ transport sites responsive to vitamin D metabolites [117]. We could speculate that under acidic fermentation conditions a caecal hypertrophy appears [20] which in turn may increase the number of these distal sites and probably $\mathrm{Ca}$ uptake. Changes in the concentration of calbindin-D9K in the mucosa of the small and large intestine of rats have been reported by Ohta et al. [126]. Sharrer and Lutz [155] using an in situ perfusion method, also indicated that SCFA could directly stimulate $\mathrm{Mg}$ absorption from the colon in rats.

Oligofructose feeding has been shown to increase iron absorption in iron-deficient models $[123,128]$. Propionate, which is produced by intestinal fermentation of oligofructose, may stimulate haeme production by promoting $\delta$-aminolevulinate synthesis [73]. Also, oligofructose feeding may lead to a change in several iron-binding proteins including iron-mucin and thereby enhance iron absorption in the small intestine [28].

With regard to GOS, their presence in the diet results in an improvement in $\mathrm{Ca}$ absorption in rats whatever the calcium intake $[23,24]$. As a result, femur and tibia ash weight and their calcium contents are 
higher after feeding a GOS diet than a control diet in ovariectomised rats [25]. Dietary GOS are also able to improve magnesium absorption and to reduce calcification of kidney and heart in the magnesium-deficient rat model [26]. To explain their potential positive effects, an important increase in mineral concentration in the liquid phase of caecum related to a high production of SCFA has also been suggested.

In humans, there are few studies about the effect of prebiotic agents on mineral absorption. Addition of inulin was reported to improve $\mathrm{Ca}$ balance, whereas $\mathrm{Mg}$, Fe and $\mathrm{Zn}$ balances are not significantly altered [29]. Based on the animal study results, however, we could speculate that prebiotic agents may be useful for the prevention of osteoporosis in the aged individual and postmonopausal oestrogen-deficient women, as well as in anaemia or $\mathrm{Mg}$-deficient states.

\subsection{Effect on dental caries}

Indigestible sugars are not used as substrates by Streptococcus mutans which has been implicated as the causative agent of dental caries in humans and animals. Consequently such sugars exhibit low cariogenic properties.

Glucan synthesis by glucosyltransferase of serotype a-g of Streptococcus mutans is directly involved in plaque formation and cellular aggregation which is connected with dental cariogenesis. Among inulin-type fructans, nystose is a low cariogenic factor. It is not used as a substrate for water-insoluble glucan formation [72]. Such results have also been demonstrated for soybean oligosaccharides and panose, an IMO component $[90,191]$.

Dental caries occur also as a result of the decalcification of enamel and dentine of teeth by organic acids produced by bacteria in dental plaque. Kaneko et al. [82] demonstrated that the hydrogenated derivate of IMO (IMH) could be considered as a low cariogenic factor in humans since it decreases the acidogenic response of dental plaque.

\section{CONCLUSION AND PERSPECTIVES}

With regard to their possible beneficial properties mentioned above, prebiotic agents seem to be adapted to the nutrition of consumers who are more and more worried about their 'health capital'. In Japan, 35 approved foods containing oligosaccharides as active ingredients have been listed since 1996 as "foods for specified health use" (FOSHU) [30]. Moreover, non-digestible oligosaccharides (mainly inulin-type fructans, IMO, palatinose, GOS, soybean oligosaccharides and xylo oligosaccharides) are considered by the European Commission (DGXII AIRII-CT94-1095) as functional food ingredients [179]. In general terms, a functional food ingredient can be defined as "a food ingredient which affects physiological functions of the body in a targeted way so as to have positive effects which may, in due course, justify health claims" [142, 143, 145].

Their potential benefits for health should not, however, mask their putative unfavourable effects. Fermentation of prebiotic agents by colonic flora could lead to gaseous symptoms. Stone-Dorshow and Levitt [166] showed that in volunteers receiving a constant daily amount of oligofructose $(5 \mathrm{~g}$ three times a day with meals), gaseous symptoms (i.e. flatulence, bloating and abdominal discomfort) were significantly increased compared to control subjects ingesting sucrose. Moreover, severe symptoms (i.e. borborygmi, abdominal cramps and diarrhoea) could appear from $30 \mathrm{~g} \cdot \mathrm{d}^{-1}$ feeding of oligofructose $[14,17]$. We could expect that tolerance to indigestible sugars depends on the degree of adaptation of the colonic microflora to ferment these sugars. Malabsorption of osmotic fermentable sugars could result in diarrhoea when the capacity of the colonic flora to 
ferment these low-molecular-weight carbohydrates is exceeded [64]. Prolonged ingestion of non-absorbable sugars such as lactulose may result in changes in metabolic activity of the colonic flora, mainly a fall in breath excretion of $\mathrm{H}_{2}$, which in turn could increase its ability to ferment sugar and therefore reduce its laxative effect [47]. We suppose that this adaptative response of the colonic flora may be different according to the tested prebiotic agents. The importance of the osmotic effect of indigestible carbohydrates possibly implicated in diarrhoea symptoms may also be determined by the concentration of sugar leaving the stomach. Thus, factors which are related to the slow-down gastric emptying (i.e. energy content of the meal, the solid content and viscosity) must be taken into account [14].

To palliate these undesirable effects, a second generation of oligosaccharides needs to be developed. This could be achieved with non-digestible carbohydrates obtained by partial controlled enzymatic hydrolysis of natural high MW fermentable carbohydrate polymers such as soluble fibres (pectins or guar gum). These hydrolyses could be performed with a pre-purified endo-hydrolase isolated from a filamentous fungi. Another strategy has also been promoted by Orafti (Tienen, Belgium): native inulin is processed to produce long-chain fructans by applying industrial physical separation technique [35]. Such compounds are commercially available under the trade name 'Raftiline HP'. Polysaccharides with higher MW (ranging from 5 to $100 \mathrm{kDa}$ ) than those presently available should produce less gas as they may be less quickly fermented in the large intestine. In contrast to high MW inulin, selective fermentation of these putative compounds by bifidobacteria or lactobacilli remains, however, very speculative. Indeed, native pectins or guar gum are not selectively used by lactic-acid bacteria [154]. Thus, increasing viscosity may be of great interest because as we have seen previously (see section 4.3.) the lipid lowering effect of indigestible carbohydrates seems to be related in large part to their viscosity properties [97]. Moreover, charged carbohydrates with a very high MW (>100 kD), mainly pectins, are well known for their potential unfavourable action on mineral bioavailability [7, 86]. Decreasing their MW enhances intestinal absorption of minerals. For instance, the intestinal absorption of iron is determined in part by the solubility of iron-pectin complex which is directly connected with its MW [86]. Finally, we could speculate that the ideal products would be those which combine both beneficial properties of low MW prebiotic agents on mineral digestibility and marked lipid lowering effects of dietary fibres.

Presently, a typical prebiotic effect is considered as the result of an increase in bifidobacteria flora. The fact that inulintype fructans increase bifidobacteria as well as breath hydrogen in humans $[1,58]$, however, needs to be commented because these bacteria do not produce gas. Moreover, in vitro fermentations with human faecal or rat caecal microflora indicate that inulintype fructans typically increase the production of butyrate. As bifidobacteria do not produce butyrate, such results confirm that populations other than the bifidobacteria are implicated. Probably, prebiotic agents are degraded by many gut micro-organisms and not just by a limited number of species which includes bifidobacteria. Maybe a complex bacterial trophic chain is implicated in the prebiotic intestinal fermentation process. Because bifidobacteria has a very well-adapted enzymatic equipment to degrade prebiotic agents through its $\beta$-fructosidase [183], we could logically suppose that it is the first and the more easily detectable species involved in this chain. Then, hydrolysis of prebiotic agents by bifidobacteria, by decreasing $\mathrm{pH}$ of the intestinal contents, may inhibit or stimulate the growth of other endogenous species. Besides, inhibitory effects on other endogenous species (i.e. Escherichia coli and clostridia) have been clearly demonstrated [58]. However, by modifying intestinal bacterial balances or 
through the production of fermentation byproducts, bifidobacteria are possibly able to selectively promote other endogenous bacteria species. The principal nitrogen source for colonic bacteria proliferation is protein not digested in the small intestine, including that of endogenous origin such as digestive enzymes or sloughed mucosal cells [104]. If the demands of fermentation are too great, as we could suspect with prebiotic agents, nitrogen deficiency could appear [173]. Some species of bifidobacteria, mainly B. bifidum, B. thermophilum, B. adolescentis, $B$. dentum, $B$. animalis and $B$. infantis when they grow without organic nitrogen sources, can excrete considerable amounts of various amino acids (alanine, valine, threonine and aspartic acid) into the medium [108]. Thus, one possibility is that an imbalance occurs in the ratio of carbohydrate/ organic nitrogen source [114], which in turn could adjust the metabolism pathway of bifidobacteria to the use of mineral nitrogen source (ammonium salts) and consequently to the liberation of amino acids. The decrease in renal nitrogen excretion after feeding oligosaccharides [192] may be in agreement with such a hypothesis. Because certain bacteria (i.e. bacteroides, fusobacteria and anaerobic cocci) can synthesise polyamines by decarboxylation of the amino acids, amino acids may be selectively used for bacterial proliferation of other intestinal species. To evaluate the consistence of such a hypothesis, the effects of prebiotics on other possible bacterial by-product pools such as intestinal spermidine, putrescine and cadaverine should be investigated. Also, it is possible that a part of the SCFA pool served as fuel for other bacterial developments. This hypothesis has not yet been investigated for practical reasons which reside in the difficulty to clearly identify various species and genera of faecal bacteria. In the coming years, it is probable that reproducible markers such as RNA probes should be developed to assess the accurate intestinal microflora composition after a prebiotic feeding period.
The potential health benefits caused by consumption of prebiotic agents must be discussed (table II). Which of the referred health attributes are feasible/usable? The most well-known effect of prebiotic agents is the stimulation of the growth of bifidobacteria. This fact has been clearly demonstrated in rats as well as in humans $[18,57,77,179]$. Moreover, associated decrease in potential harmful and putrefactive bacteria has also been demonstrated in humans $[58,172,179]$. The protective effect against colorectal cancers through the simultaneous increase in the growth of bifidobacteria and the decrease in the number of putrefactive bacteria has, however, not yet been established in humans. For instance, a correlation between oligofructose-induced bifidobacteria growth with a decrease in some reductive enzymes has not yet been presently established. Buddington et al. [18] indicated that oligofructose supplementation leads to a decrease in both $\beta$-glucuronidase and glycocholic acid hydroxylase activities, whereas Bouhnik et al. [15] demonstrated no change in reductive activities. Moreover, the relation between a decrease in some reductive enzymes and the prevention of colorectal cancers has not been proven. Presently, beneficial action of inulintype fructans through its intestinal fermentation potency has been reported in humans during intestinal pathology state where microbial variables such as potential harmful bacteria are exacerbated. For instance, excision of the colon followed by ileal pouch-anal anastomosis has become a frequently used surgical alternative to permanent ileostomy in patients with ulcerative colitis or familial adenomatous polyposis. Alles et al. [2] demonstrated that inulin-type fructans can act positively in these pouchitis patients by decreasing cytotoxicity of pouch contents (reduction of amino acidderived isobutyrate by $94 \%$ and isovalerate by $77 \%$ ). Today, there is only evidence from animal studies that lipid metabolism is affected by inulin-type fructans. Moreover, there is no indication of an hypolipi- 
daemic effect in human subjects for other type of non-digestible oligosaccharides [179]. Also, beneficial effects of prebiotics on lipid metabolism in human subjects are often observed in pathology states such as diabetes mellitus where a hyperlipidaemia occurs [185]. In healthy humans, changes in lipidaemia after feeding inulin-type fructans have not yet been reported. These human studies were conducted with inulin, $20 \mathrm{~g} \cdot \mathrm{d}^{-1}[101]$ and $14 \mathrm{~g} \cdot \mathrm{d}^{-1}$ [132] for a period of 4 weeks. This result suggests that if lipidlowering effects of inulin are to be observed in humans, larger doses or longer periods of feeding may be required [171]. Moreover, because hepatic de novo lipogenesis is likely to be the target of the hypotriglyceridaemic effect of inulin-type fructans in the rat, the apparent lack of effect observed in healthy humans, who eat much fewer carbohydrates but more lipids than rodents, does not demonstrate the absence of an effect [144]. In conclusion, the animal studies are only the basis for further ongoing studies investigating other aspects of lipid metabolism. For instance, glucagon-like peptide- 1 and glucose-dependent insulinotropic polypeptide have direct anabolic insulin-like action on lipid metabolism [89]. Further research revealed that this hypolipidaemic effect of inulin-type fructans might be induced (partly) by hormonal changes in rats [93]. The precise contribution of these hormones in the antilipogenic effect of prebiotic agents remains, however, to be elucidated. Inulin-type fructans have been reported to decrease postprandial insulinaemia in rats [94]. Interestingly, this hormone plays a major role in the regulation of muscle protein synthesis and degradation [88], suggesting a possible involvement of non-digestible oligosaccharides in such a metabolism. By depressing cholesterolaemia, Non-digestible oligosaccharides may act on regulation of glucocorticoids, another hormone type involved in protein metabolism [110]. Such a hypothesis, to our knowledge, has never been investigated. Moreover, gene expression of lipogenic enzymes such as fatty acid synthase in liver remains to be clarified [179]. Regarding the action on mineral bioavailability, few studies have been performed in humans. Only in the rat, the stimulation of $\mathrm{Ca}, \mathrm{Mg}$ and Fe absorption by inulin-type fructans or GOS has been repeatedly confirmed [179]. Differences between the rat and human mechanisms involved in digestibility of minerals are, however, very important. For instance, coprophagy in many rodent species $[61,78]$ can alter the fermentation of undigestible carbohydrates in the hindgut and therefore may affect the absorption of minerals [43, $67,124]$. Thus, we could not directly extrapolate results obtained from animal models to humans. In the present time, there is only promising evidence that consumption of inulin-type fructans results in increased $\mathrm{Ca}$ absorption in human subjects [179].

In the future, physiological effects of oligosaccharide consumption will certainly continue to be elucidated, functional properties will be more widely understood and it is expected that the number and diversity of applications of oligosaccharides in foods (individually) in combination with probiotics (synbiotics) [179] will increase.

\section{REFERENCES}

[1] Alles M.S., Hautvast J.G.A., Nagengast F.M., Hartemink R., Van Laere K.M.J., Jansen J.B.M.J., Fate of fructo-oligosaccharides in the human intestine, Br. J. Nutr. 76 (1996) 21 1-221.

[2] Alles M.S., Katan M.B., Salemans J.M.J.I., Van Laere K.M.J., Gerichhausen M.J.W., Rozendaal M.J., Nagengast F.M., Bacterial fermentation of fructooligosaccharides and resistant starch in patients with an ileal pouch-anal anastomosis, Am. J. Clin. Nutr. 66 (1997) 1286-1292.

[3] Anderson J.W., Chen W.J.L., Plant fiber: carbohydrate and lipid metabolism, Am. J. Clin. Nutr. 32 (1979) 346-363.

[4] Anderson J., Story L., Sieling B., Chen W.J.L., Hypocholesterolemic effects of oat bran or bean intake for hypercholesterolemic men, Am. J. Clin. Nutr. 40 (1984) 1146-1155.

[5] Anderson J.W., Tietyen-Clark J., Dietary fiber: hyperlipidemia, hypertension and coronary heart disease, Am. J. Gastroenterol. 81 (1986) 907-919. 
[6] Bach Knudsen K.E., Hessov I., Recovery of inulin from Jerusalem artichoke (Helianthus tuberosus $\mathrm{L}$.) in the small intestine of man, $\mathrm{Br}$. J. Nutr. 74 (1995) 101-113.

[7] Bagheri S., Guéguen L., Effect of wheat bran and pectin on the absorption and retention of phosphorus, calcium, magnesium and zinc by the growing pig, Reprod. Nutr. Dev. 25 (1985) 705-716.

[8] Bailey J.S., Blankenship L.C., Cox, N.A., Effect of fructooligosaccharide on Salmonella colonization of the chicken intestine, Poult. Sci. 70 (1991) 2433-2438.

[9] Ballongue J., Schumann C., Quignon P., Effects of lactulose and lactitol on colonic microflora and enzymatic activity, Scand. J. Gastroenterol. 32 (1997) 41-44.

[10] Berger J.L., Lee B.H., Lacroix C., Immobilization of $\beta$-galactosidases from Thermus aquaticus YT-1 for oligosaccharides synthesis, Biotechnol. Techn. 9 (1995) 601-606.

[11] Berger J.L., Lee B.H., Lacroix C., Oligosaccharides synthesis by free and immobilized $\beta$-galactosidases from Thermus aquaticus YT-1, Biotech. Lett. 17 (1995) 1077-1080.

[12] Beynen A., Vaartjes W., Geelen M., Acute effects of insulin on fatty acid metabolism in isolated hepatocytes, Horm. Metab. Res. 12 (1980) 425-430.

[13] Bircher J., Müller J., Guggenheim P., Haemmerli U.P., Treatment of chronic portal systemic encephalopathy with lactulose, Lancet i (1966) 890.

[14] Bornet F.R.J., Undigestible sugars in food products, Am. J. Clin. Nutr. 59 (1994) 763S-769S.

[15] Bouhnik Y., Flourié B., Riottot M., Bisetti N., Gailing M.F., Guibert A., Bornet F., Rambaud J.C., Effects of fructo-oligosaccharides ingestion on fecal bifidobacteria and selected metabolic indexes of colon carcinogenesis in healthy humans, Nutr. Cancer 26 (1996) 21-29.

[16] Bouhnik Y., Flourié B., Dagayabensour L., Pochart P., Gramet G., Durand M., Rambaud J.C., Administration of transgalactooligosaccharides increases fecal bifidobacteria in healthy humans, J. Nutr. 127 (1997) 444-448.

[17] Briet F., Achour L., Flourié B., Beaugerie L., Pellier P., Franchisseur C., Bornet F., Rambaud J-C., Symptomatic response to varying levels of fructo-oligosaccharides consumed occasionally or regularly, Eur. J. Clin. Nutr. 49 (1995) 501-507.

[18] Buddington R.K., Williams C.H., Chen S.C., Witherly S.A., Dietary supplement of neosugar alters the fecal flora and decreases activities of some reductive enzymes in human subjects, Am. J. Clin. Nutr. 63 (1996) 709-716.

[19] Bustos-Fernandez L., de Paolo I., Hamamura S., Gonzalez E., Celener D., Caldarini M., Does secretion influence rat colonic absorption and secretion?, Am. J. Gastroenterol. 70 (1978) 265-269.

[20] Campbell J.M., Fahey G.C., Wolf B.W., Selected indigestible oligosaccharides affect large bowel mass, cecal and fecal short-chain fatty acids, $\mathrm{pH}$ and microflora in rats, J. Nutr. 127 (1997) 130-136.

[21] Chadwick R.W., George S., Claxton L.D., Role of the gastrointestinal mucosa and microflora in the bioactivation of dietary and environmental mutagens or carcinogens, Drug Metab. Rev. 24 (1992) 425-492.

[22] Challa A., Rao D.R., Chawan C.B., Shackelford C., Bifidobacterium longum and lactulose suppress azoxymethane-induced colonic aberrant crypt foci in rats, Carcinogenesis 18 (1997) 517-521.

[23] Chonan O., Watanuki M., Effect of galactooligosaccharides on calcium absorption in rats, J. Nutr. Sci. Vitaminol. 41 (1995) 95-104

[24] Chonan O., Watanuki M., The effect of $6^{\prime}$-galactooligosaccharides on bone mineralization of rats adapted to different levels of dietary calcium, Int. J. Vitam. Nutr. Res. 66 (1996), 244-249.

[25] Chonan O., Matsumoto K., Watanuki M., Effect of galactooligosaccharides on calcium absorption and preventing bone loss in ovariectomized rats, Biosci. Biotechnol. Biochem. 59 (1995), 236-239.

[26] Chonan O., Takahashi R., Yasui H., Watanuki M., Effects of $\beta$-1-4 linked galactooligosaccharides on use of magnesium and calcification of the kidney and heart in rats fed excess dietary phosphorus and calcium, Biosci. Biotechnol. Biochem. 60 (1996) 1735-1737.

[27] Christi S.U., Gibson G.R., Cummings J.H., Role of dietary sulphate in the regulation of methanogenesis in the human large intestine, Gut 33 (1992) 1234-1238

[28] Conrad M.E., Umbreit J.N., Moore E.G., Rat duodenal iron-binding protein mobiferrin is a homologue of calreticulin, Gastroenterology 104 ( 1993) 1700-1704.

[29] Coudray C., Bellanger J., Castiglia-Delavaud C., Rémésy C., Vermorel M., Rayssiguier Y., Effect of soluble or partly soluble dietary fibres supplementation on absorption and balance of calcium, magnesium, iron and zinc in healthy young men, Eur. J. Clin. Nutr. 51 (1997) 375-380.

[30] Crittenden R.G., Playne M.G., Production, properties and applications of food-grade oligosaccharides, Trends Food Sci. Technol. 7 (1996) 353-360.

[31] Cummings J.H., Englyst H.N., Measurement of starch fermentation in the human large intestine, Can. J. Physiol. Pharmacol. 69 (1991) $121-129$ 
[32] Cummings J.H., Gibson G.R., Macfarlane G.T., Quantitative estimates of fermentation in the hindgut of man, Acta Vet. Scand. 86 (1989) 76-82.

[33] Debruyn A., Alvarez A.P., Sandra P., De Leenheer L., Isolation and identification of $\beta$-D-fructofuranosyl- $(2,1)$-D-fructose, a product of the enzymatic hydrolysis of the inulin from Cichorium intybus, Carbohydr. Res. 235 (1992) 303-308.

[34] De Leenheer L., Hoebregs H., Progress in the elucidation of the composition of chicory inulin, Starch 46 (1994) 193-196.

[35] De Leenheer L., Production and use of inulin: industrial reality with a promising future, in: Van Bekkun H., Röper H., Voragen F. (Eds.), Carbohydrates as Organic Raw Materials (vol. III), New York, 1996, pp. 67-92.

[36] Delzenne N.M., Roberfroid M.B., Physiological effects of non digestible oligosaccharides, Food Sci. Technol. 27 (1994) 1-6.

[37] Delzenne N.M., Kok N., Fiordaliso M.F., Deboyser D.M., Goethals F.M., Roberfroid M.B., Dietary fructooligosaccharides modify lipid metabolism in rats, Am. J. Clin. Nutr. 57 (1993) 820S.

[38] Delzenne N., Aertssens J., Verplaetse N., Roccaro M., Roberfroid M., Effect of fermentable fructo-oligosaccharides on energy and nutrients absorption in the rat, Life Sci. 57 (1995) 1579-1587.

[39] Demigné C., Levrat M.-A., Younes H., Rémésy C., Interactions between large intestine fermentation and dietary calcium, Eur. J. Clin. Nutr. 49 (1985) 235-238.

[40] Demigné C., Yacoub C., Rémésy C., Fafournoux $\mathrm{P}$., Effects of absorption of large amounts of volatile fatty acids on rat liver metabolism, J. Nutr. 116 (1986) 77-86.

[41] Duan K.J., Sheu D.C., Lin M.T., Hsueh C., Reaction mechanism of isomaltooligosaccharides synthesis by $\alpha$-glucosidase from Aspergillus carbonarious, Biotechnol. Lett. 16 (1994) 1151-1156.

[42] Dubois C., Armand M., Senft M., Portugal H., Pauli A.M., Bernard P.M., Lafont H., Lairon D., Chronic oat bran intake alters post-prandial lipemia and lipoproteins in healthy adults, Am. J. Clin. Nutr. 61 (1995) 325-333.

[43] Ebino K.Y., Studies on coprophagy in experimental animals, Exp. Anim. 42 (1993) 1-9

[44] Ellegärd L., Andersson H., Boseus I., Inulin and oligofructose do not influence the absorption of cholesterol, $\mathrm{Ca}, \mathrm{Mg}, \mathrm{Zn}, \mathrm{Fe}$, or bile acids but increase energy excretion in ileostomy subjects, Eur. J. Clin. Nutr. 51 (1997) 1-5.

[45] Fernandez M.L., Sun D.M., Tosca M., McNamara D.J., Guar gum effects on plasma lowdensity lipoprotein and hepatic cholesterol metabolism in guinea pigs fed low-and highcholesterol diets: a dose-response study, Am. J. Clin. Nutr. 61 (1995) 127-134.

146] Fiordaliso M.F., Kok N., Desager J.P., Goethals F., Deboyser D., Roberfroid M., Delzenne N., Oligofructose-supplemented diet lowers serum and VLDL concentrations of triglycerides, phospholipids and cholesterol in rats, Lipids 30 (1995) 163-167.

[47] Flourié B., Briet F., Florent C., Pellier P., Maurel M., Rambaud J.C., Can diarrhea induced by lactulose be reduced by prolonged ingestion of lactulose?, Am. J. Clin. Nutr. 58 (1993) 369-375.

[48] Fuller R., Probiotics in man and animals, J. Appl. Bacteriol. 66 (1989) 365-378.

[49] Gallaher D., Hassel C.A., Lee K.J., Gallaher C.M., Viscosity and fermentability as attributes of dietary fiber responsible for the hypocholesterolemic effect in hamsters, J. Nutr. 123 (1993) 244-252.

[50] Gallaher D.D., Stallings W.H., Blessing L.L., Busta F.F., Brady L.J., Probiotics, cecal microflora, and aberrant crypts in the rat colon, J. Nutr. 126 (1996) 1362-1371.

[51] Garleb K.A., Snook J.T., Marcon M.J., Wolf B.W., Johnson W.A., Effect of fructooligosaccharide containing enteral formulas on subjective tolerance factors, serum chemistry profiles, and fecal bifidobacteria in healthy adult male subject, Microb. Ecol. Health Dis. 9 (1996) 279-285.

[52] Gee J.M., Blackburn N.A., Johnson I.T., The influence of guar gum on intestinal cholesterol transport in the rat, Br. J. Nutr. 50 (1983) 215-224.

[53] Gibbons G.F., Assembly and secretion of hepatic very-low-density lipoprotein, Biochem. J. 268 (1990) 1-13.

[54] Gibson G.R., Wang X., Bifidogenic properties of different types of fructooligosaccharides, Food Microbiol. 11 (1994) 491-498.

[55] Gibson G.R., Wang X., Enrichment of bifidobacteria from human gut contents by oligofructose using continuous culture, Microbiol. Lett. 118 (1994) 121-128.

[56] Gibson G.R., Wang X., Inhibitory effects of bifidobacteria on other colonic bacteria, J. Appl. Bacteriol. 77 (1994) 412-420.

[57] Gibson G.R., Roberfroid M.B., Dietary modulation of the human colonic microbiota: introducing the concept of prebiotics, J. Nutr. 125 (1995) 1401-1412.

[58] Gibson G.R., Beatty E.B., Wang X., Cummings J.H., Selective stimulation of bifidobacteria in the human colon by fructo-oligofructoses $(\mathrm{GFn}+\mathrm{Fm})$ and inulin, Gastroenterology 108 (1995) 975-982.

[59] Gibson G., Dietary modulation of the human gut microflora using prebiotics, Br. J. Nutr. 80 (1998) 209-212. 
[60] Giffhorn-Katz S., Katz N.R., Carbohydratedependent induction of fatty acid synthase in primary cultures of rat hepatocytes, Eur. J. Biochem. 159 (1986) 513-518.

[61] Giovannetti P.M., Effect of coprophagy on nutrition, Nutr. Res. 2 (1982) 335-349.

[62] Goldin B.R., Swenson L., Dwyer J., Sexton M., Gorbach S.L., Effect of diet and Lactobacillus acidophilus supplements on human faecal bacterial enzymes, J. Natl. Cancer Inst. 62 (1980) 255-261.

[63] Gorbach S.L., Goldin B.R., The intestinal microflora and the colon cancer connection, Rev. Infect. Dis. 12 (1990) 252-261.

[64] Hammer H.F., Fine K.D., Santa Ana C.A., Porter J.L., Schiller L.R., Fordtran J.S., Carbohydrate malabsorption. Its measurement and its contribution to diarrhea, J. Clin. Invest. 84 (1989) 1056-1062.

[65] Hayashi S., Ito K., Nonoguchi M., Takasaki Y., Kiyohisa I., Immobilization of a fructosyl-transferring enzyme from Aureobasidium sp on Shirasu porous Glass, J. Ferment. Bioeng. 72 (1991) 68-70.

[66] Hayashi S., Kinoshita J., Nonoguchi M., Takasaki Y., Imada K., Continuous production of 1-kestose by $\beta$-fructofuranosidase immobilized on Shirasu porous Glass, Biotechnol. Lett. 13 (1991) 395-398.

[67] Heijnen A.M.P., Brink E.J., Lemmens A.G., Beynen A.C., Ileal $\mathrm{pH}$ and apparent absorption of magnesium in rats fed on diets containing either lactose or lactulose, Br. J. Nutr. 70 (1993) 747-756.

[68] Hidaka H., Hirayama M., Sumi N., A fructooligosaccharide-producing enzyme from Aspergillus niger ATCC 20611 , Agric. Biol. Chem. 52 (1988) 1181-1187.

[69] Hill R.J., The role of colon anaerobes in the metabolism of bile acids and steroids and relationship to colon cancer, Cancer 36 (1975) 2387-2400.

[70] Hosoya N., Dhorranintra B., Hidaka H., Utilization of $\left[\mathrm{U}^{14}-\mathrm{C}\right]$ fructooligosaccharides in man as energy resources, J. Clin. Biochem. Nutr. 5 (1988) 67-74.

[71] Howard M.D., Gordon D.T., Garleb K.A., Kerley M.S., Dietary fructooligosaccharide, xylooligooligosaccharide and gum arabic have variable effects on cecal and colonic microbiota and epithelial cell proliferation in mice and rats, J. Nutr. 125 (1995) 2604-2609.

[72] Ikeda T., Kurita T., Hidaka H., Michaleck S.M., Hirasawa M., Low-cariogenicity of the tetrasaccharide nystose, Gen. Pharmacol. 21 (1990) 175-179.

[73] Imaizumi K., Hirata K., Yasni S., Sugano M. Propionate enhances synthesis and secretion of bile acids in primary cultured rat hepatocytes via succinyl CoA, Biosci. Biotechnol. Biochem. 56 (1992) 1894-1896
[74] Isaksson G., Lundquist I., Ihse I., Effect of dietary fiber on pancreatic enzyme activity in vitro, Gastroenterology 82 (1982) 918-924.

[75] Ito M., Degushi Y., Miyamori A., Matsumoto K., Kikuchi M., Kobayachi Y., Yauma T., Kan T., Effect of administration of galacto-oligosaccharides on the human faecal microflora, stool, weight and abdominal sensation, Microb. Ecol. Health Dis. 3 (1990) 285-292.

[76] Ito M., Deguchi Y., Matsumoto K., Kimura M., Onodera N., Yajima T., Influence of galactooligosaccharides on the human fecal microflora, J. Nutr. Sci. Vitaminol. 39 (1993) 635-640.

[77] Ito M., Kimura M., Deguchi Y., Miyamoriwatabe A., Yajima T., Kan T., Effects of transgalactosylated disaccharides on the human intestinal microflora and their metabolism, J. Nutr. Sci. Vitaminol. 39 (1993) 279-288.

[78] Jackson K.A., Topping D.L., Prevention of coprophagy does not alter the hypocholesterolaemic effects of oat bran in the rats, Br. J. Nutr. 70 (1993) 211-219.

[79] Jerkins A.A., Liu W., Lee S., Sul H.S., Characterization of the murine mitochondrial glycerol3 -phosphate acetyltransferase promoter, J. Biol. Chem. 270 (1995) 1416-1421.

[80] Jung K.H., Yun J.W., Kang K.R., Lim J.Y., Lee H.J., Mathematical model for enzymatic production of fructo-oligosaccharides from sucrose, Enzyme Microb. Technol. 11 (1989) $491-494$

[81] Kaneko T., Kohmoto T., Kikuchi H., Shiota M., Iino H., Mitsuoka T., Effects of isomaltooligosaccharides with different degrees of polymerization on human fecal bifidobacteria, Biosci. Biotechnol. Biochem. 58 (1994) 2288-2290.

[82] Kaneko T., Matsukubo T., Yatake T., Muramatsu Y., Takaesu Y., Evaluation of acidogenicity of commercial isomaltooligosaccharides mixture and its hydrogenated derivative by measurement of $\mathrm{pH}$ response under human dental plaque, Biosci. Biotechnol. Biochem. 59 (1995) 372-377.

[83] Kaneko T., Yakayama A., Suzuki M., Digestibility characteristics of isomaltooligosaccharides in comparison with several saccharides using the rat jejunum loop method, Biosci. Biotechnol. Biochem. 59 (1995) 1190-1194.

[84] Katsurada A., Iritani N., Fukuda H., Matsumura Y., Nishimoto N., Nogushi T., Tanaka T., Effects of nutrients and hormones on transcriptional and post-transcriptional regulation of fatty acid synthase in rat liver, Eur. J. Biochem. 190 (1990) 427-433.

[85] Kikuchihayakawa H., Kimura M., Watanuki M., Adaptation of rate of organic acid production of hindgut bacteria to chronic intake of galactooligosaccharide in the rat, J. Nutr. Sci. Vitaminol. 43 (1997) 357-368. 
[86] Kim M., Highly esterified pectin with low molecular weight enhances intestinal solubility and absorption of ferric iron in rats, Nutr. Res. 18 (1998) 1981-1994.

[87] Kim M.H., In M.J., Cha H.J., Yoo Y.J., An emperical rate equation for the fructooligosaccharide-producing reaction catalazed by $\beta$-fructofuranosidase, J. Ferment. Bioeng. 82 (1996) 458-463.

[88] Kimball, S.R., Jurasinski C.V., Lawrence J.C., Jefferson L.S., Insulin stimulates protein synthesis in skeletal muscle by enhancing the association of eIF4E and eIF4G, Am. J. Physiol. 272 (1997) C754-C759.

[89] Knapper J.M., Puddicombe S.M., Morgan L.M., Fletcher J.M., Investigations into the actions of glucose dependent insulinotropic polypeptide and glucagon-like peptide-1 (7-36) amide on lipoprotein lipase activity in explants of rat adipose tissue, J. Nutr. 125 (1995) 183-188.

[90] KogaT., Horikoshi T., Fujiwara T., Hamada S., Effects of panose on glucan synthesis and cellular adherence by Streptococcus mutans, Microbiol. Immunol. 32 (1988) 25-31.

[91] Kohmoto T., Fukui F., Takaku H., Mitsuoka T., Dose-response test of isomaltooligosaccharides for increasing fecal bifidobacteria, Agric. Biol. Chem. 55 (1991) 2157-2159.

[92] Kohmoto T., Tsuji K., Kaneko T., Shiota M., Fukui F., Takaku H., Nakagawa Y., Ichikawa T., Kobayashi S., Metabolism of ${ }^{13} \mathrm{C}$-isomaltooligosaccharides in healthy men, Biosci. Biotechnol. Biochem. 56 (1992) 937-940.

[93] Kok N., Roberfroid M., Robert A., Delzenne N., Involvement of lipogenesis in the lower VLDL secretion induced by oligofructose in rats, $\mathrm{Br}$. J. Nutr. 76 (1996) 881-890.

[94] Kok N.N., Morgan L.M., Williams C.C., Roberfroid M.B., Thissen J.P. Delzenne N., Insulin, glucagon-like peptide 1, glucose-dependent insulinotropic polypeptide and insulin-like growth factor I as putative mediators of the hypolipidemic effect of oligofructose in rats, J. Nutr. 128 (1998) 1099-1998.

[95] Kulkarni N., Reddy B.S., Inhibitory effect of Bifidobacterium longum cultures on the azoxymethane-induced aberrant crypt foci formation and fecal bacterial $\beta$-glucuronidase, Proc. Soc. Exp. Biol. Med. 207 (1994) 278-283.

[96] Kurishi T., Tsuda M., Imanaka T., Continuous production of panose by immobilized neopullulanase, J. Ferment. Bioeng. 73 (1992) 198-202.

[97] Lairon D., Dietary fibres: effects on lipid metabolism and mechanisms of action, Eur. J. Clin. Nutr. 50 (1996) 125-133.

[98] Levrat M.A., Rémésy C., Demigné C., Influence of inulin on urea and ammonia in the rat cecum: consequences on nitrogen excretion, J. Nutr. Biochem. 4 (1993) 351-356.
[99] Levrat M.A., Favier M.L., Moundras C., Rémésy C., Demigné C., Morand C., Role of dietary propionic acid and bile acid excretion in the hypocholesterolemic effects of oligosaccharides in rats, J. Nutr. 124 (1994) 531-538.

[100] Lin Y., Vonk R.J., Slooff M.J., Kuipers F., Smit M.J., Differences in propionate-induced inhibition of cholesterol and triacylglycerol synthesis between human and rat hepatocytes in primary culture, Br. J. Nutr. 74 (1995) 197-207.

[101] Luo J., Rizkalla S.W., Alamowitch C., Boussairi A., Blayo A., Barry J-L., Laffitte A., Guyon F., Bornet F.R.J., Slama G., Chronic consumption of short-chain fructooligosaccharides by healthy subjects decreased basal hepatic glucose production but had no effect on insulinstimulated glucose metabolism, Am. J. Clin. Nutr. 63 (1996) 939-945.

[102] Lutz T., Sharrer E., Effect of short-chain fatty acids on calcium absorption by the rat colon, Exp. Physiol. 76 (1991) 615-618.

[103] MacFarlane G.T., MacFarlane S., Factors affecting fermentation reactions in the large bowel, Proc. Nutr. Soc. 52 (1993) 367-373.

[104] Macfarlane G.T., Cummings J.H., Allison C., Protein degradation by human intestinal bacteria, J. Gen. Microbiol. 132 (1986) 1647-1656.

[105] Macfarlane G.T., Hay S., Gibson G.R., Influence of mucin on glycosidase, protease and arylamidase activities of gut bacteria grown in a 3-stage continuous culture system, J. Appl. Bacteriol. 66 (1989) 407-417.

[106] Mason V.C., Metabolism of nitrogenous compounds in the large gut, Proc. Nutr. Soc. 43 (1984) 45-53.

[107] Matheson H.B., Colon I.S., Story J.A., Cholesterol $7 \alpha$-hydroxylase activity is increased by dietary modification with Psyllium hydrocolloid, pectin, cholesterol and cholestyramine in rats, J. Nutr. 125 (1995) 454-458.

[108] Matteuzi D., Crociani F., Emaldi O., Amino acids produced by Bifidobacteria and some Clostridia, Ann. Microbiol. Institut Pasteur 129B (1978) 175-181.

[109] Mazur A., Rémésy C., Gueux E., Levrat A.M., Demigné C., Effects of diet rich in fermentable carbohydrates on plasma lipoprotein levels and on lipoprotein catabolism in rats, J. Nutr. 120 (1990) 1037-1045.

[110] Millward D.J.B., Odera B., Bates C., The role of insulin, corticosterone and other factors in the acute recovery of muscle protein synthesis on refeeding food-deprived rats, Biochem. J. 216 (1983) 583-587.

[111] Mitsuoka T., Bifidobacteria and their role in human health, J. Ind. Microbiol. 6 (1990) 263-268.

[ L12] Molis C., Flourié B., Ouarne F., Gailing M.F., Lartigue S., Guibert A., Bornet F., Galmiche J.P., Digestion, excretion and energy value of fruc- 
tooligosaccharides in healthy humans, Am. J. Clin. Nutr. 64 (1996) 324-328.

[113] Moore W.E.C., Cato E.P., Holdeman L.V., Some current concepts in intestinal bacteriology, Am. J. Clin. Nutr. 31 (1978) 533-542.

[114] Morita T., Kasaoka S., Oh-Hashi A., Ikai M., Numasaki Y., Kirayama S., Resistant proteins alter cecal short-chain fatty acid profiles in rats fed high amylose cornstarch, J. Nutr. 128 (1998) 1156-1164.

[115] Mortensen P.B., Effect of oral-administrated lactulose on colonic nitrogen metabolism and excretion, Hepatology 16 (1992) 1350-1356.

[116] Mozaffar Z., Nakanishi K., Matsuno R., Production of oligosaccharides by glutaraldehyde treated and immobilized $\beta$-galactosidase from Bacillus circulans, Biotechnol. Lett. 10 (1988) 805-808.

[117] Nellans H., Goldsmith R., Transepithelial calcium transport by rat cecum: high efficiency absorption site, Am. J. Physiol. 240 (1981) G424-G531.

[118] Nishina P., Freeland R., Effects of propionate on lipid biosynthesis in isolated rat hepatocytes, J. Nutr. 120 (1990) 668-673.

[119] Ohta A., Osakabe N., Yamada K., Saito Y., Hidaka $\mathrm{H}$., Effect of fructooligosaccharides on $\mathrm{Ca}, \mathrm{Mg}$ and $\mathrm{P}$ absorption in rats, J. Jpn. Soc. Nutr. Food Sci. 46 (1993) 123-1 29.

[120] Ohta A., Baba S., Takizawa T., Adachi T., Effects of fructooligosaccharides on the absorption of magnesium in the magnesium-deficient rat model, J. Nutr. Sci. Vitaminol, 40 (1994) 171-180.

[121] Ohta A., Ohtuki M., Takizawa T., Inaba H., Adachi T., Kimura S., Effects of fructooligosaccharides on the absorption of magnesium and calcium by cecectomized rats, Int. J. Vitam. Nutr. Res. 64 (1994) 316-323.

[122] Ohta A., Ohtsuki M., Baba S., Adachi T., Sakata T., Sakaguchi E., Calcium and magnesium absorption from the colon and rectum are increased in rats fed fructooligosaccharides, J. Nutr. 125 (1995) 2417-2424.

[123] Ohta A., Ohtsuki M., Baba S., Takizawa T., Effects of fructooligosaccharides on the absorption of iron, calcium and magnesium in irondeficient anemic rats, J. Nutr. Sci. Vitaminol. 41 (1995) 281-291.

[124] Ohta A., Baba S., Ohtsuki M., Taguchi A., Adachi T., Hara H., Prevention of coprophagy modifies magnesium absorption in rats fed with fructo-oligosaccharides, Br. J. Nutr. 75 (1996) 775-784.

[125] Ohta A., Baba S., Ohtsuki M., Takizawa T., Adachi T., Hara H., In vivo absorption of calcium carbonate and magnesium oxide from the large intestine in rats, J. Nutr, Sci. Vitaminol. 43 (1997) 35-46.
[126] Ohta A., Motohashi Y., Ohtsuki M., Hirayama M., Adachi T., Sakuma K., Dietary fructooligosaccharides change the concentration of calbindinD9K differently in the mucosa of the small and large intestine of rats, J. Nutr. 128 (1998) 934-939.

[127] Ohta A., Ohtsuki M., Baba S., Hirayama M., Adachi T., Comparison of the nutritional effects of fructo-oligosaccharides of different sugar chain length in rats, Nutr. Res. 18 (1998) 109-120.

[128] Ohta A., Ohtsuki M., Uehara M., Hosono A., Hirayama M., Adachi T., Hara H., Dietary fructooligosaccharides prevent postgastrectomy anemia and osteopenia in rats, J. Nutr. (1998) $485-489$.

[129] Oku T., Tokunaga T., Hosoya N., Nondisgestibility of a new sweetner fructooligosaccharide Neosugar in rat, J. Nutr. 114 (1984) 1574-1581.

[130] Oyarzabal O.A., Conner D.E., In vitro fructooligosaccharide utilization and inhibition of Salmonella spp. by selected bacteria, Poult. Sci. 74 (1995) 1418-1425.

[13I] Patel V., Saunders G., Bucke C., Production of fructooligosaccharides by Fusarium oxysporum, Biotechnol. Lett. 16 (1994) 1139-1144.

[132] Pedersen A., Sandstrom B., Van Amelsvoot J.M.M., The effect of ingestion of inulin on blood lipids and gastrointestinal symptoms in healthy females, Br. J. Nutr. 78 (1997) 215-222.

[133] Pretlow T.P., O'Riordan M.A., Pretlow T.G., Stellato T.A., Aberrant crypts in human colonic mucosa: putative preneoplastic lesions, J. Cell. Biochem. 16G (1992) 55-62.

[134] Prior R.L., Topping D.C., Visek W.J., Metabolism of isolated chick small intestinal cell. Effects of ammonia and various salts, Biochemistry 13 (1974) 178-183.

[135] Rajala S., Salminen S., Seppänen J., Vapaatalo H., Treatment of chronic constipation with lactitol sweetened yoghurt supplemented with guar gum and wheat bran in elderly hospital patients, Comp. Gerontol. 2 (1988) 83-86.

[136] Rechkemmer G., Ronnau K., Engelhardt W.V., Fermentation of polysaccharides and absorption of short chain fatty acids in the mammalian hindgut, Comp. Biochem. Physiol. 90 (1988) 563-568.

[137] Reddy B.S., Prevention of colon cancer by preand probiotics: evidence from laboratory studies, Br. J. Nutr. 80 (1998) 219-223.

[138] Reddy B.S., Rivenson A., Inhibitory effect of Bifidobacterium longum on colon, mammary, and liver carcinogenesis induced by 2 -amino3 methylimidazol (4,5-f) quinoline, a food mutagen, Cancer Res. 53 (1993) 3914-3918.

[139] Reddy B.S., Hamid R., Rao C.V., Effect of dietary oligofructose and inulin on colonic preneoplastic aberrant crypt foci inhibition, Carcinogenesis 18 (1997) 1371-1374. 
[140] Rémésy C., Demigné C., Changes in availability of glucogenic and ketogenic substrates and liver metabolism of fed and starved rats, Ann. Nutr. Metab. 27 (1983) 57-70.

[141] Rémésy C., Levrat M.A., Gamet I., Demigne C., Cecal fermentations in rats fed oligosaccharides (inulin) are modulated by dietary calcium level, Am. J. Physiol. 264 (1993) G 855-G 862.

[142] Roberfroid M.B., A functional food: chicory fructooligosaccharides, a colonic food with prebiotic activity, World of Ingredients MarchApril (1995) 42-44.

[143] Roberfroid M.B., Functional effects of food components and the gastrointestinal system: chicory fructooligosaccharides, Nutr. Rev. 54 (1996) 38-42.

[144] Roberfroid M.B., Prebiotics and synbiotic: concepts and nutritional properties, Br. J. Nutr. 80 (1998) 197-202.

[145] Roberfroid M.B., Delzenne N., Dietary fructans, Annu. Rev. Nutr. 18 (1998) 117-143.

[146] Roberfroid M., Gibson G.R., Dezenne N., The biochemistry of oligofructose, a non-digestible dietary fiber: an approach to calculate its caloric value, Nutr. Rev. 51 (1993) 137-146.

[147] Roberfroid M.B., Van Loo J.A.E., Gibson G.R., A review of the bifidogenic nature of chicory inulin and its hydrolysis products, J. Nutr. 128 (1997) 11-19.

[148] Roberton A.M., Stanley R.A., In vitro utilization of mucin by Bacteroides fragilis, Appl. Environ. Microbiol. 43 (1982) 325-330.

[149] Rowland I.R., Rummey C.J., Coutts J.T., Lievense L., Effect of Bifidobacterium longum and inulin on gut bacterial metabolism and carcinogen induced aberrant crypt foci in rats, Carcinogenesis 2 (1998) 281-285.

[150] Rumessen J.J., Bode S., Hamberg O., Hoyer E.G., Fructans of Jerusalem artichokes: intestinal transport, absorption, fermentation and influence on blood glucose, insulin and $\mathrm{C}$-peptide responses in healthy subjects, Am. J. Clin. Nutr. 52 (1990) 675-681.

[151] Saito Y., Takano T., Rowland I., Effects of soybean oligosaccharides on the human gut microflora in in vitro culture, Microb. Ecol. Health Dis. 5 (1992) 105-1 10.

[152] Sakaguchi E., Sakoda C., Toramaru Y., Caecal fermentation and energy accumulation in the rat fed on indigestible oligosaccharides, $\mathrm{Br}$. J. Nutr. 80 (1998) 469-476.

[153] Salminen S., Salminen E., Lactulose, lactic acid bacteria, intestinal microecology and mucosal protection, Scand. J. Gastroenterol. 32 (1997) 45-48.

[154] Salyers A.A., Vercellotti J.R., West S.E.H., Wilkins T.D., Fermentation of mucin and plant polysaccharide by strains of Bacteroides from the human colon, Appl. Environ. Microbiol. 33 (1977) 319-322.
[155] Scharrer E., Lutz T., Effects of short chain fatty acids and $\mathrm{K}$ on absorption of $\mathrm{Mg}$ and other cations by the colon and caccum, Z. Ernahrungswiss. 29 (1990) 162-168.

[156] Schneeman B.O., Effect of plant fiber on lipase, trypsin and chymotrypsin activity, J. Food. Sci. 43 (1978) 634-635

[157] Schulz A.G.M., Amelsvoort J.M.M., Beynen A.C., Dietary native resistant starch but not retrograded resistant starch raises magnesium and calcium absorption in rats, J. Nutr. 123 (1993) 1724-1731.

[158] Schumann W. C., Magnusson I., Chandramouli V., Rumaran K., Wahren J., Landan B.R., Metabolism of $\left[2-{ }^{14} \mathrm{C}\right]$ acetate and its use in assessing hepatic Krebs cycle activity and gluconeogenesis, J. Biol. Chem. 266 (1991) 6985-6990.

[159] Shin H.J., Yang J.W., Galacto-oligosaccharide production by $\beta$-galactosidase in hydrophobic organic media, Biotechnol. Lett. 16 (1994) 1157-1162.

[160] Shin H.J., Yang J.W., Galactooligosaccharide synthesis from lactose by Penicillium funiculosum cellulase, Biotechnol. Lett. 18 (1996) $143-144$

[161] Simon G.L., Gorbach S.L., Intestinal flora in health and disease, Gastroenterology 86 (1984) 174-193.

[162] Singh J., Rivenson A., Tomita M., Shimamura S., Ishibashi N., Reddy B.S., Bifidobacterium longum, a lactic acid-producing intestinal bacterium inhibits colon cancer and modulates the intermediate biomarkers of colon carcinogenesis, Carcinogenesis 18 (1997) 833-841.

[163] Sparks J.D., Sparks C.E., Insulin regulation of triacylglycerol-rich lipoprotein synthesis and secretion, Biochem. Biophys. Acta 1215 (1994) 9-32.

[164] Stellwag E.J., Hylemon P.B., 7- $\alpha$-Dehydroxylation of cholic acid and chenodeoxydeoxycholic acid by Clostridium leptum, J. Lipid Res. 20 (1979) 352-333.

[165] Stephen A.M., Cummings J.H., Mechanisms of action of dietary fibre in the human colon, Nature 284 (1980) 283-284.

[166] Stone-Dorhow T., Levitt M.D., Gaseous response to ingestion of a poorly absorbed fructo-oligosaccharide sweetener, Am. J. Clin. Nutr. 46 (1987) 61-65.

[167] Storch K., Anderson J.W., Young V.R., Oat bran muffins lower serum cholesterol of healthy young people, Clin. Res. 34 (1984) 710A.

[168] Takahashi Y., Takagi Y., Toda M., Kashiwabara C., Ishiyama R., Kinoshita T., Effects of neosugar in chronic renal-failure patients, Third Neosugar Research Conference, Tokyo, 1986.

[169] Tanaka R., Takayama H., Morotomi M. Kuroshima T., Ueyama S., Matsumoto K. Kuroda A., Mutai M., Effects of administration 
of TOS and Bifidobacterium breve 4006 on the human fecal flora, Bifidobacteria Microflora 2 (1983) 17-24.

[170] Tannock G.W., Probiotic properties of lacticacid bacteria: plenty of scope for fundamental R \& D, Tibtech 15 (1997) 270-274.

[171] Taylor G.R.J., Williams C.M., Effects of probiotics and prebiotics on blood lipids, $\mathrm{Br}$. J. Nutr. 80 (1998) 225-230.

[172] Terada A., Hara H., Kataoka M., Mitsuoka T., Effect of lactulose on the composition and metabolic activity of the human faccal flora, Microb. Ecol. Health Dis. 5 (1992) 43-50.

[173] Topping D.L., Gooden J.M., Brown I.L., Biebrick D.A., Mcgrath L., Trimble R.P., Choct M., Illman R.J., A high amylose (amylomaize) starch raises proximal large bowel starch and increases colon length in pigs, J. Nutr. 127 (1997) 615-622.

[174] Trautwein E.A., Rieckhoff D., Kunath-Rau A., Erbersdobler H.F., Psyllium, not pectin or guar gum, alters lipoprotein and biliary bile acid composition and fecal sterol excretion in the hamster, Lipids 33 (1998) 573-582.

[175] Trinidad T.P., Wolever T.M., Thompson L.U., Interactive effects of calcium and short chain fatty acids on absorption in the distal colon of man, Nutr. Res. 13 (1993) 417-425.

[176] Turley S.D., Dietschy J.M., Mechanisms of LDL-cholesterol lowering action of Psyllium hydrophilic mucilloid in the hamster, Biochem. Biophys. Acta 1255 (1995) 177-184.

[177] Ueda K., Immunity provided by colonized enteric bacteria, Bifidobacteria Microflora 5 (1986) 67-72.

[178] Van Loo J., Coussement P., De Leenheer L., Hoebregs H., Smits G., On the presence of inulin and oligofructose as natural ingredients in the western diet, CRC Crit. Rev. Food. Sci. Nutr. 35 (1995) 525-552.

[179] Van Loo J., Cummings J., Delzenne N., Englyst H., Franck A., Hopkins M., Kok N., Macfarlane G., Newton D., Quigley M., Roberfroid M., Van Vliet T., Van Den Heuvel E., Functional food properties of non-digestible oligosaccharides: a consensus report from the ENDO project (DGXII AIRII-CT94-1095), Br. J. Nutr. 81 (1999) 121-132.

[180] Viallard V., Endogenous urea as a nitrogen source for microorganisms of the rabbit digestive tract, Ann. Nutr. Metab. 28 (1984) 151-155.

[181] Waldroup A.L., Skinner J.T., Hierholzer R.E., Waldroup P.W., An evaluation of fructooligosaccharide in diets for broiler chickens and effects on Salmonellae contamination of carcasses, Poult. Sci. 72 (1993) 643-650.

[182] Wang X., Comparative aspects of carbohydrate fermentation by colonic bacteria, Ph.D. thesis, University of Cambridge, UK, 1993.
[183] Wang X., Gibson G.R., Effects of the in vitro fermentation of oligofructose and inulin by bacteria growing in the human large intestine, J. Appl. Bacteriol. 75 (1993) 373-380.

[184] Wright R.S., Anderson J.W., Briges S.R., Propionate inhibits hepatocyte lipids synthesis, Proc. Soc. Exp. Biol. Med. 195 (1990) 26-29.

[185] Yamashita K., Kawai K., Itakura M., Effect of fructo-oligosaccharides on blood glucose and serum lipids in diabetic subjects, Nutr. Res. 4 (1984) 961-966.

[186] Yamazaki S., Kamimura H., Momose H., Kawashima T., Ueda K., Protective effect of bifidobacteria-monoassociation against lethal activity of Escherichia coli, Bifidobacteria Microflora 1 (1982) 55-64.

[187] Yamazaki S., Machii K., Tsuyuki S., Momose H., Kawashima T., Ueda K., Immunological responses to monoassociated Bifidobacterium longum and their relation to prevention of bacterial invasion, Immunology 56 (1985) 43-50.

[188] Yanahira S., Kobayashi T., Suguri T., Nakakoshi M., Miura S., Ishikawa H., Nakajima J., Formation of oligosaccharides from lactose by Bacillus circulans $\beta$-galactosidase, Biosci. Biotechnol. Biochem. 59 (1995) 1021-1026.

[189] Yanahira S., Morita M., Aoe S., Suguri T., Takada Y., Miura S., Nakajima, I., Effects of lactitol-oligosaccharides on calcium and magnesium absorption in rats, J. Nutr. Sci. Vitaminol. 43 (1997) 123-132.

[190] Yazawa K., Tamura Z., Search for sugar sources for selective increase of bifidobacteria, Bifidobacteria Microflora (1982) 39-44.

[191] Yoshida T., Aono W., Minami T., Takei T., Izumitani A., Ooshima T., Sobue S., Caries-inducing activity of soybean-oligosaccharide (SOR) in vitro and in experimental dental caries of rats, Shoni Shikagaku Zasshi 29 (1991) 95-101.

[192] Younes H., Garleb K., Behr S., Rémésy C., Demigné $\mathrm{C}$., Fermentable fibers or oligosaccharides reduce urinary nitrogen excretion by increasing urea disposal in the rat cecum, J. Nutr. 125 (1995) 1010-1016.

[193] Younes H., Demigné C., Behr S.R., Garleb K.A., Rémésy $\mathrm{C}$., A blend of dietary fibers increases urea disposal in the large intestine and lowers urinary nitrogen excretion in rats fed a low protein diet, J. Nutr. Biochem. 7 (1996) 474-480.

[194] Young J., European market developments in prebiotic-and probiotic-containing foodstuffs, Br. J. Nutr. 80 (1998) 231-233.

[195] Yun J.W., Fructooligosaccharides-occurence, preparation, and application, Enzyme Microb. Technol. 19 (1996) 107-117.

[196] Yun J.W., Song K.S., The production of highcontent fructo-oligosaccharides from sucrose by the mixed-enzyme system of fructosyltransferase and glucose oxidase, Biotechnol. Lett. 15 (1993) 573-576. 
[197] Yun J.W., Jung K.H., Jeon Y.J., Lee J.H., Continuous production of fructo-oligosaccharides from sucrose by immobilized cells of Aureobasidium pullulans, Appl. Biochem. Biotechnol. 24/25 (1992) 299-308.

[198] Yun J.W., Lee M.G., Song K.S., Batch production of high-content fructo-oligosaccharides from sucrose by the mixed-enzyme system of $\beta$-fructofuranosidase and glucose oxidase, J. Ferment. Bioeng. 77 (1994) 159-163.
[199] Yun J.W., Kang S.C., Song K.S., Continuous production of fructooligosaccharides from sucrose by immobilized fructosyltransferase, Biotechnol. Tech. 9 (1995) 805-808.

[200] Yun J.W., Kim D.H., Kim B.W., Son S.K., Comparison of sugar compositions between inulo-and fructo-oligosaccharides produced by different enzymes forms, Biotechnol. Lett. 19 (1997) 553-556. 